\title{
CRITÉRIOS E INDICADORES DE SUSTENTABILIDADE \\ EM FLORESTAS MANEJADAS POR COMUNIDADES
}

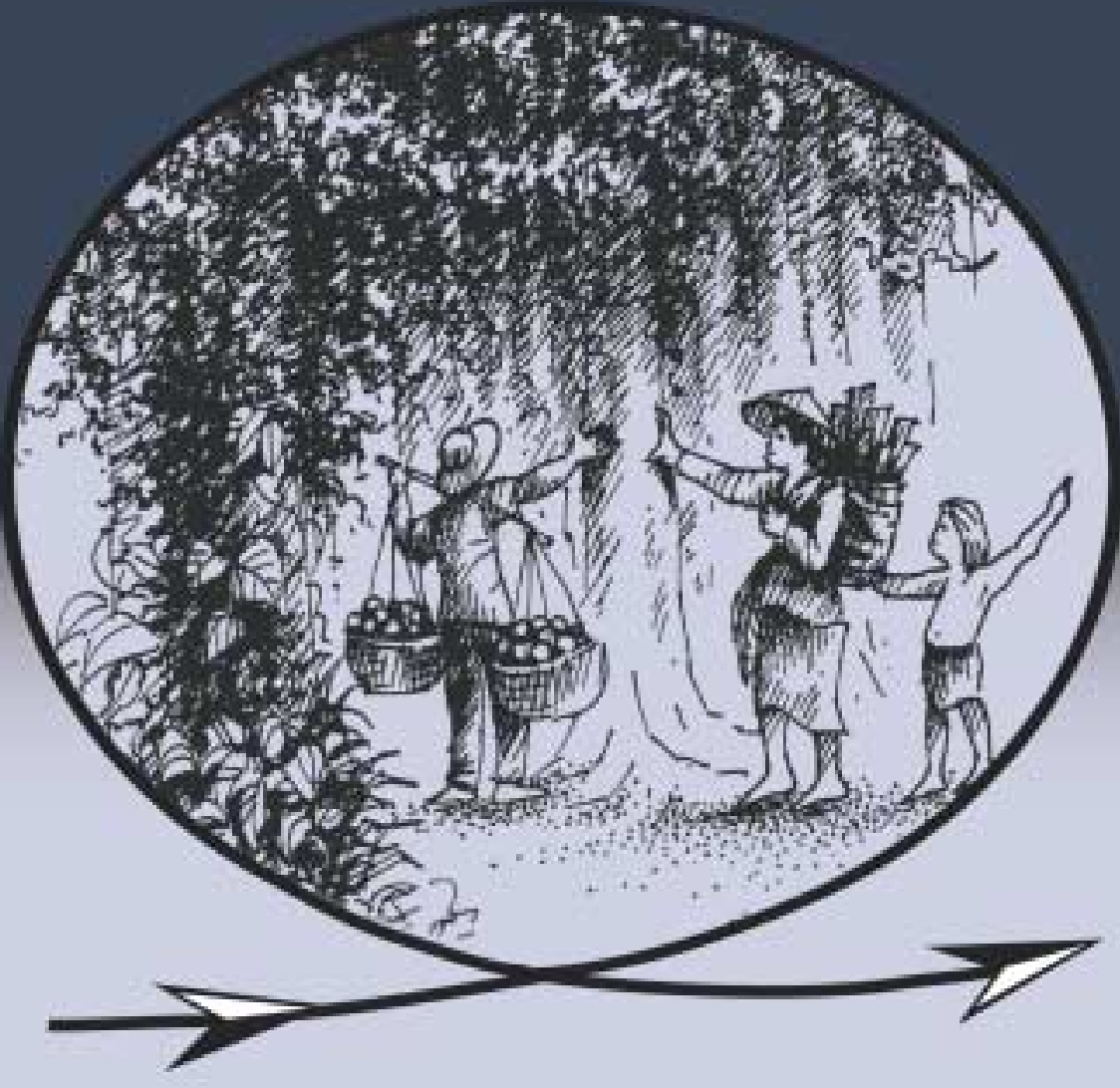

Bill Ritchie

Cynthia McDougall

Mandy Haggith

Nicolette Burford de Oliveira 


\section{CIFOR}

O CIFOR foi estabelecido em 1993 como parte integrante do Grupo Consultivo de Pesquisa Agrícola Internacional (CGIAR, do inglês Consultative Group on International Agricultural Research) em resposta às preocupações globais com as consequiências sociais, ambientais e econômicas da perda e degradação de florestas. A pesquisa do CIFOR produz o conhecimento e os métodos necessários para se melhorar o bem-estar de povos que dependem da floresta e para ajudar países tropicais a manejar suas florestas sabiamente, a fim de que possam usufruir seus benefícios de forma duradoura. A pesquisa é feita em mais de vinte países, em cooperação com um grande número de parceiros. Desde a sua fundação, o CIFOR desempenhou um papel central em influir as políticas florestais globais e nacionais.

\section{CGIAR}

O Grupo Consultivo de Pesquisa Agrícola Internacional (CGIAR), estabelecido em 1971, é uma associação informal de quase 60 doadores do setor público e privado que apóia uma rede de 16 centros internacionais de pesquisa agrícola. A missão do CGIAR é contribuir para a segurança alimentar e a erradicação da pobreza nos países em desenvolvimento através de pesquisa, parcerias, capacitação e apoio a políticas públicas. O CGIAR promove o desenvolvimento sustentável agrícola baseado no manejo ecologicamente viável dos recursos naturais. 


\title{
CRITÉRIOS E INDICADORES DE SUSTENTABILIDADE EM FLORESTAS MANEJADAS POR COMUNIDADES: UM GUIA INTRODUTÓRIO
}

\author{
Bill Ritchie \\ Cynthia McDougall \\ Mandy Haggith
}

Nicolette Burford de Oliveira

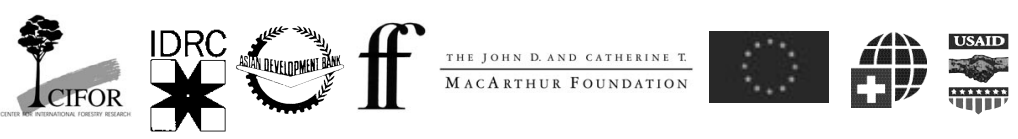


(C)2001 por Centro para Pesquisa Florestal Internacional (CIFOR) Todos os direitos reservados. Publicado em Fevereiro de 2001 Impresso por SMT Grafika Desa Putera, Indonésia llustrado por April Mansyah Traduzido por Gláucia Barreto Revisado por Laura Viarengo e Marli Mattos

\section{ISBN 979-8764-64-1}

\section{Publicado por}

Centro para Pesquisa Florestal Internacional Bogor, Indonésia

Endereço: P.O. Box 6596 JKPWB, Jakarta 10065, Indonésia Tel.: +62 (251) 622622; Fax: +62 (251) 622100

Correio eletrônico: cifor@cgiar.org

Página na internet: http://www.cifor.cgiar.org

\section{Com apoio do}

Centro de Pesquisa de Desenvolvimento Internacional (IDRC)

Banco Asiático de Desenvolvimento (ADB)

Fundação Ford (FF)

Fundação MacArthur (MAF)

União Européia (UE)

Corporação Suiça para o Desenvolvimento (SDC)

Agência Norte Americana de Desenvolvimento Internacional (USAID) 


\section{Índice}

Prefácio $\quad$ V

Agradecimentos vii

Introdução 1

Quem deveria ler este guia? 3

Linhas gerais 3

1. Manejo Comunitário de Florestas (MCF) 5

1.1 Por que o Manejo Comunitário de Florestas é importante? 5

1.2 O que ajuda o MCF a funcionar? 8

1.3 Quais as atuais ameaças ao MCF? 8

1.4 Adaptando-se às mudanças 9

1.5 Adaptando-se às mudanças em parceria 10

1.6 Como C\&l podem ajudar 11

2. O que são C\&l? 15

2.1 Definindo C\&l 16

2.2 Exemplos de C\&l 18

3. Desenvolvendo e usando um conjunto de C\&I 23

3.1 Experiência anterior: Resumo da pesquisa de C\&l do CIFOR 23

3.2 Preparando-se para desenvolver e usar C\&l: Perguntas a fazer antes de você começar $\quad 27$

3.3 Definindo os atores: Quem precisa ser envolvido? 33

3.4 O ponto de partida para C\&l: Conjuntos básicos, padrões ou visões? 35

3.5 Desenvolvendo C\&l: Algumas etapas práticas 38 
3.6 "Filtrando" os C\&l: Eles são os melhores para o trabalho?

3.7 Primeiro teste: Fazendo uma avaliação rápida dos C\&l

3.8 Monitoramento: Colocando os C\&l em prática

\section{Conteúdo dos C\&I}

Introduzindo os C\&l selecionados dos três locais de testes do CIFOR

Princípio 1. 0 bem-estar da comunidade está garantido

1.a Organizações/instituições comunitárias

e participação

1.b Mecanismos para manejo local (por exemplo, normas, regras, regulamentos etc.)

1.c Administração de conflitos

66

1.d Autoridade para manejar (posse)

Princípio 2. 0 bem-estar das pessoas está garantido

2.a Saúde e alimentação

2.b Prosperidade (modos de vida, distribuição de custos e benefícios, eqüidade)

2.c Sabedoria, ética de sustentabilidade e troca de conhecimento

2.d Acordos sobre a posse na comunidade

Princípio 3. A saúde da floresta está garantida 79

3.a Planejamento (zoneamento e áreas protegidas) 80

3.b Manejo das funções do ecossistema (terra, água e fogo)

3.c Intervenções produtivas 1 (agricultura e agrofloresteria) 
3.d Intervenções produtivas 2 (PFNMs vegetais) 87

3.e Intervenções produtivas 3 (PFNMs animais) 89

3.f Intervenções produtivas 4 (madeira) 91

3.g Saúde da floresta 1 (biodiversidade) 92

3.h Saúde da floresta 2 (estrutura e regeneração) 94

3.i Diversidade da paisagem (fragmentação e mosaicos)

Princípio 4. O Meio ambiente externo é favorável ao MSFC 98

4.a Relacionamentos com terceiros 99

4.b Estruturas política e legal (excluindo posse) 101

4.c Economia 103

4.d Educação e informação 105

$\begin{array}{ll}\text { Solicitação de contribuições } & 107\end{array}$

$\begin{array}{ll}\text { Referências } & 108\end{array}$

Alguns endereços úteis para contatos relacionados a MCF 113

Apêndice 1. Resumo das questões e comparações entre os locais de teste de C\&l para MCF do CIFOR

Apêndice 2. Conjuntos e diretrizes usados como base pelas equipes de testes de C\&l para MCF 


\section{Prefácio}

Este guia foi elaborado como uma contribuição ao esforço mundial para melhorar o manejo florestal, o bem-estar humano e a sustentabilidade dos recursos naturais. Para que o guia seja útil, é preciso considerar três pontos importantes ao usá-lo:

1) Como acontece com qualquer ferramenta deste tipo, todo o conteúdo deste guia necessita ser analisado e adaptado ao contexto do local no qual ele estará sendo usado. Nós não o consideramos um "plano", mas um "estímulo" a ações apropriadas...

2) O sucesso na implementação da abordagem sugerida neste guia dependerá da boa compreensão, do compromisso e das habilidades do usuário em processos e abordagens participativas. Isso não significa que somente "especialistas em processos participativos" devem usá-lo. Ao contrário, significa que se houver uma carência de qualquer um desses pré-requisitos, ela deverá ser suprida antes ou durante os processos associados aos C\&l (por exemplo, através das leituras ou contatos sugeridos nas referências).

Além disso, em relação ao primeiro fator, como a abordagem de C\&l para MCF e os processos para o monitoramento são adaptados para uso local, é extremamente importante que essas adaptações criem e maximizem oportunidades para a troca de aprendizagem e apropriação dos processos. Por exemplo, apesar de o guia poder oferecer algumas idéias para "estruturação de C\&l para MCF", ele não se aprofundará sobre os tipos de métodos participativos que podem ser melhor usados em diferentes grupos para fazer tal estruturação. 
Esperamos que os implementadores deste guia tragam os métodos participativos e adaptáveis que serão necessários em cada contexto. Antecipamos que em todos os contextos, isso incluirá adaptações tais como:

- Jogos adequados ao local para introduzir idéias;

- Substituição de palavras escritas por representações pictoriais ou outras atividades de acordo com o nível educacional;

- Desenvolvimento de estratégias para superar barreiras na participação (tais como gênero, classe social etc.)

3) Este é um trabalho em progresso! O CIFOR e seus colaboradores continuam a trabalhar nessa esfera de ação, e agradecem sua contribuição para aperfeiçoar este guia. 


\section{Agradecimentos}

Este manual é produto dos esforços conjuntos e dos pensamentos de muitas pessoas durante muitos anos. Gostaríamos especialmente de expressar nossa gratidão aos membros das comunidades de Akak/Bitetele e Eyek II (Província Central, República dos Camarões); Cachoeira do Maró e São Pedro (Pará, Brasil); Bedigong e Darok (Kalimantan Oriental, Indonésia) que participaram dos testes de campo de C\&l para MCF, os quais tornaram este trabalho possível graças à sua generosa participação e sabedoria. Também agradecemos e parabenizamos o trabalho dos membros da equipe multidisciplinar, facilitadores e auxiliares envolvidos nesta pesquisa -- muito numerosos para serem mencionados individualmente, mas cujos esforços foram tão valiosos e preciosos. Gostaríamos de agradecer e citar pelo menos as principais instituições colaboradoras: o Projeto de Desenvolvimento Florestal Social (SFDP) (Sanggau, Kalimantan) financiado pela GTZ e Ministério da Silvicultura Indonésio; FERDA (Bogor, Indonésia); ONADEF (República dos Camarões); WWF (República dos Camarões); o Sindicato dos Trabalhadores Rurais de Santarém (STR-Santarém), e o Projeto Saúde e Alegria, Santarém, Brasil.

No CIFOR, agradecemos a Ravi Prabhu, Godwin Kowero e Michael Spilsbury, que contribuíram com excelentes comentários e encorajamento. Agradecemos a Yvonne Byron pela edição deste trabalho, a Gideon Suharyanto por sua criatividade e orientação no visual desta publicação, e a Rahayu Koesnadi por todo o apoio. Ramon Gerrits contribuiu significativamente para esta versão do guia através de seu apoio contante na coordenação e edição. Nosso agradecimentos também para César Sabogal, pelas suas contribuições editoriais. 
Por último, porém de não menor importância, agradecemos às agências financiadoras que tornaram este manual possível - Centro de Pesquisa de Desenvolvimento Internacional (IDRC); Banco Asiático de Desenvolvimento (ADB); Fundação Ford (FF); Fundação MacArthur (MAF); União Européia (UE); Corporação para o Desenvolvimento Suíço (SDC); e Agência Norte Americana de Desenvolvimento Internacional (USAID) que deram apoio financeiro à pesquisa sobre $\mathrm{C} \&$ para MCF tratados nesta publicação. Agradecemos não apenas os recursos, mas também o encorajamento, sabedoria e paciência dispensados. 


\section{Introdução}

O manejo florestal comunitário é um cenário complexo e dinâmico, o que levou o CIFOR a realizar um programa de pesquisa que tem por objetivo desenvolver e testar Critérios e Indicadores (C\&l) apropriados para avaliar a sustentabilidade de Florestas Manejadas por Comunidades (FMC). ${ }^{1} \quad$ Foram realizados três locais: no Brasil, na Indonésia e na República dos Camarões, como parte de um projeto mais amplo denominado "Avaliação da Sustentabilidade do Manejo Florestal" do CIFOR, o qual deu origem a esta pesquisa. Ela irá explorar em profundidade o papel dos C\&l no manejo adaptável e colaborativo feito por comunidades e outros atores florestais.

Este guia baseia-se nos resultados da pesquisa sobre C\&l para MCF do CIFOR até o momento, e sugere o potencial existente para aplicação prática e seu posterior desenvolvimento dentro da comunidade. Baseados na experiência nos três sítios de testes do CIFOR, apresentamos C\&l como uma ferramenta participativa para manejo comunitário sustentável de florestas (i.e., manejo comunitário de florestas no qual o fluxo de bens e senviços dessas florestas pode ser mantido sem reduzir sua qualidade ou valor para as gerações futuras). 0 objetivo deste manual é auxiliar

\footnotetext{
1 Usamos o termo "Manejo Comunitário de Florestas" (MCF) ou "Florestas Manejadas por Comunidades" (FMC) ao invés de "Manejo Florestal Comunitário" (MFC) a fim de manter a estrutura conceitual bastante ampla. No momento em que incluímos áreas que estão sob manejo exclusivo de uma comunidade ou comunidades, nós também estaremos nos referindo a áreas manejadas, parcialmente, por comunidades, incluindo casos de manejo colaborativo ou manejo em conjunto entre comunidades e com outros atores. Reconhecemos que este último caso de manejo por atores múltiplos apresenta muitos desafios que não são tratados completamente aqui. Planejamos continuar a explorá-los através de nossa pesquisa e comunicação com outros, e tratá-los mais completamente em publicações futuras.
}

${ }^{2}$ Burford de Oliveira (1999) e Burford de Oliveira et al. (1999). 
gestores florestais baseados nas comunidades, assim como profissionais e parceiros, a desenvolverem em comum acordo, um conjunto de $C \& I$ facilmente compreendido, o qual foi gerado com base no conhecimento compartilhado e nas melhores práticas. Este conjunto de $\mathrm{C} \& \mathrm{l}$ pode ser usado para fornecer um sistema para monitorar e avaliar mudanças-chave, ou para retornar informações ao sistema de manejo comunitário de florestas, de modo a orientar as ações posteriores para a sustentabilidade.

C\&l podem ajudar as comunidades a:

- Estabelecer metas para manejo florestal sustentável;

- Monitorar seu próprio desempenho;

- Avaliar as informações-chaves obtidas da aplicação dos C\&;

- Aprender a partir das informações obtidas;

- Adaptar seu manejo levando em consideração as mudanças observadas;

- Tomar melhores decisões sobre as futuras ações; e

- Comunicar-se efetivamente sobre os impactos de fatores externos, inclusive de políticas florestais.

Este guia resume nossas experiências e propõe uma opção que pode ser adotada pelos gestores e profissionais do MCF. Apesar de termos aprendido muito com os testes de campo e análises até o momento, ainda continuamos a pesquisar e, o que é mais importante, continuamos a aprender. Encorajamos as pessoas a adaptarem as idéias deste guia para suas próprias circunstâncias, da maneira que thes parecer mais adequada, e suas contribuições, especialmente aquelas baseadas em experiências de implementação de C\&l para MCF, serão bem-vindas. 


\section{Quem deveria ler este guia?}

Este guia é direcionado àqueles que gostariam de desenvolver e usar C\&l como uma ferramenta para melhorar o manejo comunitário de florestas. Os usuários potenciais podem ser:

- Trabalhadores de projetos de extensão/desenvolvimento e funcionários de Organizações Não-Governamentais (ONGs) engajados em atividades de MCF com pessoas locais ou em áreas com potencial para MCF;

- Funcionários públicos do departamento florestal que trabalham com comunidades no manejo comunitário ou manejo conjunto de florestas; e

- Comunidades fortemente organizadas e auto-motivadas, ativamente envolvidas em MCF incluindo aquelas interessadas em certificação, além de outras.

\section{Linhas gerais}

Parte 1 Enfatiza a importância do manejo comunitário de florestas e identifica tanto alguns elementos comuns de sucesso quanto de ameaça ao manejo. Além disso, enfatiza a necessidade de compartilhar a aprendizagem do manejo e da comunicação entre as comunidades e outros atores, por meio de acordos de manejo colaborativo, além de demonstrar a utilidade potencial dos C\&l.

Parte 2 Explica os C\&l. Esta seção apresenta a maneira pela qual a sabedoria, a informação e o conhecimento sobre o manejo florestal sustentável, quando compartilhados, podem ser estruturados em uma forma hierárquica de Princípios, Critérios, Indicadores e Verificadores.

Parte 3 Sugere uma abordagem para o desenvolvimento participativo de um conjunto local de C\&I para Florestas Manejadas Sustentavelmente por Comunidade (FMSC). Apesar deste manual não fornecer instruções detalhadas, ele oferece algumas diretrizes e 
recomendações sobre princípios-chave resultantes das lições aprendidas no trabalho do CIFOR. Em seguida, destaca uma abordagem possível para aplicar o conjunto acordado de C\&l como uma ferramenta para monitoramento e avaliação do manejo florestal, a fim de direcionar, de uma forma interativa, o manejo para a sustentabilidade.

Parte 4 Trata do conteúdo dos C\&l para MCF. O amplo alcance do conteúdo relevante é mostrado pelos exemplos dos $C \& l$ gerados nos três locais de testes do CIFOR. Esses exemplos podem ser usados como um possível ponto de partida para o desenvolvimento de C\&l apropriados para o local.

Finalmente, citamos algumas referências de materiais de apoio e manuais úteis disponíveis, incluindo relatórios completos de testes de C\&l para MCF do CIFOR.

\section{Abreviaturas usadas no Guia:}

ADF : $\quad$ Agente do Distrito Florestal

ARP : Avaliação Rural Participativa

C\&l : Critérios e Indicadores -- é uma abreviatura comumente usada para representar toda a hierarquia relacionada, ou seja, não apenas Critérios e Indicadores, mas Princípios, Critérios, Indicadores e Verificadores.

FMSC: Floresta(s) Manejada(s) Sustentavelmente por Comunidade(s)/ Manejo de Florestas

FMC : $\quad$ Floresta (s) Manejada(s) por Comunidade(s)

MCF: Manejo Comunitário de Florestas

ONG : Organização Não-Governamental

UMF : Unidade de Manejo Florestal 


\section{Manejo Comunitário de Florestas (MCF)}

\subsection{Por que o Manejo Comunitário de Florestas é importante?}

Muitas comunidades rurais, e especialmente as comunidades tradicionais, possuem uma longa tradição de manejo florestal comunitário. Isto é, o manejo dos recursos florestais é responsabilidade de uma comunidade local, e as práticas de manejo são executadas através de esforços cooperativos ou coletivos pelos membros da comunidade. Essas comunidades têm armazenado um estoque considerável de sabedoria, conhecimento e habilidades práticas, as quais podem ser usadas para ajudar a garantir o manejo sustentável de muitas florestas do mundo.

O MCF foi, e ainda é, ativamente praticado em muitos locais, de todo o mundo, de cada continente e de cada tipo de floresta, desde os trópicos até às tundras. Os sistemas e objetivos do manejo variam consideravelmente, desde pastorar carneiros no hemisfério norte usando sistemas agrossilviculturais perenes, até agricultura de corte e queima nas florestas tropicais. Tais sistemas de manejo florestal são freqüentemente baseados em um "modo de vida tradicional, contínuo, envolvendo toda a comunidade, com alto grau de independência e ritualmente aprovado".

${ }^{3}$ Conklin, H.C. 1957. Hanunoo Agricultural: a report on an integral system of shifting agriculture in the Philippines. Rome: FAO (Forestry Development paper no. 12). 
O MCF diferencia-se significativamente da visão econômica ou industrial convencional do manejo florestal pela sua amplitude de visão. As pessoas dependentes da floresta geralmente vêem sua floresta a partir de muitas e diferentes perspectivas. Por exemplo, elas podem considerar a floresta um espaço anteriormente habitado por seus ancestrais, dos quais se pode traçar a influência na paisagem ao longo do tempo. A paisagem também existe na memória das pessoas, a qual está associada a nomes de lugares, mitos e folclore.

A floresta manejada pela comunidade é um "espaço cultural".

Este espaço é onde as pessoas da floresta encontram:

- suas necessidades físicas - alimento, lenha, abrigo, remédios e ferramentas;

- suas necessidades sociais - espaço individual, familiar e comunitário;

- suas necessidades espirituais - por exemplo, sítios sagrados, cemitérios e lares espirituais; e

- suas necessidades econômicas - produtos florestais, matériaprima e emprego.

Até recentemente, os sistemas de manejo comunitário eram freqüentemente vistos como anacronismos numa época moderna, além de destruidores da floresta, ineficientes e improdutivos. Esta visão freqüentemente tem levado à condenação de tais sistemas de manejo comunitário (e às vezes, à perseguição das próprias comunidades), resultando no quase total desaparecimento das mesmas em algumas partes do mundo. Pesquisas recentes, além de uma compreensão maior de "como e por que" esses sistemas de MCF operam, estão levando a um reconhecimento crescente de sua viabilidade e valor, e também de sua importância para o funcionamento de muitos sistemas econômicos e sociais rurais. Milhões de pessoas ao redor do mundo ainda dependem de 
recursos florestais para sua sobrevivência, e continuarão a depender no futuro próximo. Da mesma forma, devido às crescentes necessidades regional, nacional e internacional de proteger os recursos hídricos e a biodiversidade, e de limitar os níveis de carbono atmosférico, as comunidades estão se tornando cada vez mais reconhecidas como sendo aliados potenciais e gestores-chave dos recursos.

Há também um número crescente de comunidades vivendo às margens das florestas, as quais não possuem as longas tradições de manejo florestal descritas acima. Embora essas comunidades, tais como transmigrantes ou reassentados, não possam compartilhar da mesma abundância de conhecimento local específico ou ter ligações espirituais com a área, elas, enquanto pessoas que vivem próximo à floresta, são atores principais e podem causar impactos positivos ou negativos significativos sobre a mesma. Esse fato, associado às lições concretas aprendidas por muitos governos ao redor do mundo, de que as pessoas locais não podem forçosamente ser privadas da floresta, claramente indica a necessidade prática de considerar as comunidades locais como gestores locais, e como tais, serem encorajadas e incluídas em esforços para a sustentabilidade.

Outra razão prática para o MCF estar sendo cada vez mais reconhecido e apoiado, independentemente da composição da comunidade, se relaciona à tendência atual de muitos governos a descentralizar e/ou devolver a responsabilidade e o manejo das florestas e de outros recursos naturais para níveis mais locais, incluindo as comunidades. Esse fato provoca aumento de interesse dentre os governos, agências de apoio, ONGs e finalmente, dentre muitas das próprias comunidades florestais em garantir e fortalecer o MCF.

\footnotetext{
${ }^{4}$ Por exemplo, ver Poffenberger (1998 em progresso).
} 


\subsection{O que ajuda o MCF a funcionar?}

Analisando as experiências no mundo, foi possível identificar um número de fatores que parecem estar associados ao manejo comunitário bem-sucedido dos recursos e produtos florestais. Tais fatores incluem:

- Participação clara dos membros da comunidade;

- Demarcação clara dos recursos florestais;

- Autoridade para manejar (segurança da posse, de fato ou de direito);

- Conhecimento comum sobre o valor dos recursos florestais;

- Conhecimento comum sobre o funcionamento da floresta;

- Dependência de instituições internas ao invés de instituições externas;

- Regras realistas definidas internamente;

- Habilidade para monitorar e impor o cumprimento das regras ;

- Mecanismos de baixo custo para resolução de conflitos;

- Capacidade para monitorar a situação dos recursos florestais; e

- Tecnologias apropriadas para apropriação de produtos florestais.

\subsection{Quais as atuais ameaças ao MCF?}

Os recursos florestais, as comunidades florestais e seus sistemas de MCF em muitas partes do mundo, continuam sob pressão crescente de:

- Mudanças nos cenários político e econômico nos quais eles operam;

\footnotetext{
${ }_{6}^{5}$ Por exemplo, ver Ostrom (1999).

Neste texto, a menos que seja especificado, quando nos referimos a regras, incluímos regras formais e informais e regulamentos (por exemplo, padrões, tabus, práticas tradicionais estabelecidas etc.)
} 
- Aumento da demanda para recursos florestais por atores fora da comunidade;

- Difusão da educação e da informação global, inclusive via mídia popular; e

- Crescimento das populações da comunidade.

Isso pode resultar na:

- Criação de novas demandas/oportunidades de mercado;

- Criação de competição para recursos florestais dos quais as comunidades dependem;

- Enfraquecimento dos sistemas tradicionais de crença, os quais sustentam seus sistemas de valores e orientam seus sistemas de manejo; e

- Aumento das expectativas e aspirações.

Onde os sistemas de MCF são ameaçados ou enfraquecidos, o resultado freqüentemente pode ser o uso insustentável da floresta, ocasionando a degradação da floresta ou desmatamento. ${ }^{7}$

\subsection{Adaptando-se às mudanças}

Todos os sistemas de MCF têm evoluído ao longo do tempo e as comunidades têm aprendido a se adaptar às mudanças em seus ambientes político, cultural e econômico e também, certamente, às mudanças em seu ambiente físico que foram provocadas por sua própria intervenção. Isso é bem ilustrado, por exemplo, por muitas comunidades que habitam nas florestas, e que desenvolveram sistemas de incorporação e cultivo intensivo de árvores de valor comercial na mesma. Isso acontece em resposta a uma redução na disponibilidade de

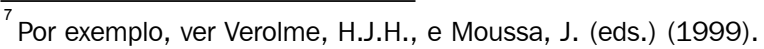


terras florestais e à maior exposição às oportunidades de mercado. No entanto, há uma preocupação crescente de que muitas comunidades que praticam o MCF possam não ser capazes de adaptar-se de forma positiva e rápida o bastante para acompanhar as muitas mudanças que se apresentam.

A mudança é rápida para a maioria dessas comunidades. Grande parte dessa mudança é provocada por fatores externos quando estradas, educação universal, informação e comunicação externas são introduzidas em suas vilas e terra natal. Apesar de muitas mudanças serem bem vindas, elas muitas vezes demonstram ter capacidade de provocar o rompimento dos sistemas de manejo tradicional.

Adaptar-se a essas mudanças pode ser muito desafiador. Além disso, pode ser muito prejudicial no caso da velocidade de mudança ultrapassar a velocidade de aprendizado sobre os impactos da mudança na comunidade e nos recursos florestais.

\subsection{Adaptando-se às mudanças em parceria}

Uma resposta aos desafios impostos pelas rápidas mudanças e pela necessidade de adaptar-se, seria as comunidades trabalharem com maior interação com outros atores, tais como ONGs e órgãos do governo em parcerias para o manejo florestal colaborativo.

Entre as dificuldades encontradas nas parcerias de manejo colaborativo, está a comunicação eficiente entre os parceiros nãocomunitários e a comunidade. 0 reconhecimento crescente do governo, das organizações de desenvolvimento rural e de outros, de que o MCF é importante e de que há necessidade de determinação política para transferir o direito de manejo para as comunidades, provoca a expectativa de que o MCF deveria 
visar uma boa administração e satisfazer as necessidades da comunidade. O significado de boa administração para os parceiros não-comunitários, muitas vezes é baseado em considerações globais mais amplas e científicas que podem não ser imediatamente reconhecidas ou compreendidas pela comunidade. Essas considerações por sua vez, podem não compreender ou representar adequadamente os interesses da comunidade. Além disso, existem múltiplos obstáculos para as comunidades expressarem efetivamente suas próprias expectativas, necessidades, conhecimento e realizações aos outros parceiros.

Essa impossibilidade de comunicar-se com eficácia pode muitas vezes resultar em uma situação de tensão no manejo colaborativo, o qual, na melhor das hipóteses, pode ser frustrado, e na pior, ser social e ambientalmente destrutivo. Tal situação também pode impedir o desenvolvimento do MCF sustentável.

\subsection{Como C\&I podem ajudar}

Critérios e Indicadores de Manejo Florestal Sustentável podem ser instrumentos úteis de aprendizagem e comunicação. Critérios e Indicadores (C\&l) genérica ou amplamente aplicáveis, se desenvolvidos em verdadeiras parcerias, têm o potencial para criar pontes entre as comunidades e o mundo exterior. Ou seja, trazendo informação sobre o conhecimento e visões do mundo exterior e levando informação sobre as visões, necessidades e realizações das comunidades.

Nossa experiência até o momento sugere fortemente que C\&l desenvolvidos localmente pelos principais atores, de uma forma participativa e colaborativa, podem ser um instrumento valioso para aprendizagem mútua entre a comunidade e parceiros, 
compartilhando conhecimento local e científico e outros conhecimentos externos, bem como direcionando ações para o manejo florestal sustentável. Os C\&l podem fornecer uma estrutura para organizar conhecimentos e informações compartilhados sobre o manejo florestal sustentável.

Desenvolver C\&l de uma maneira participativa pode:

- Extrair sabedoria, conhecimento, observação e compreensão locais;

- Dar expressão ao conhecimento tradicional;

- Reunir o conhecimento tradicional e o científico;

- Identificar lacunas ou equívocos no conhecimento;

- Fortalecer o planejamento, monitoramento, avaliação e comunicação da comunidade;

- Aumentar a apropriação da comunidade do processo de monitoramento; e

- Aumentar o poder de influência ("voz") da comunidade com relação aos outros atores.

Os C\&l resultantes desse processo podem ser usados pelas comunidades como uma ferramenta para estabelecer objetivos para o manejo florestal sustentável, guiar ações, monitorar, avaliar e obter lições do processo. Usar os C\&l em um processo interativo, pode ajudar a direcionar o manejo para a sustentabilidade.

O uso de C\&l como instrumento de monitoramento pode:

- Permitir que a comunidade estabeleça objetivos para o manejo florestal sustentável;

- Ajudar a assimilar as informações-chaves sobre os efeitos do manejo;

- Contribuir para a identificação e avaliação dos progressos alcançados em relação aos objetivos;

- Encorajar a comunidades e parceiros a apreenderem lições a partir dos impactos positivos e negativos do manejo; 
- Encorajar as comunidades a adaptarem estratégias e ações de manejo baseadas nas lições aprendidas; e

- Ajudar as comunidades a comunicarem suas experiências de manejo a outros atores.

Dependendo do contexto, os processos para desenvolver e monitorar os C\&l podem ser tanto formais quanto informais. Acreditamos que eles podem ser compatíveis e também melhorar os contextos de MCF onde há sistemas formais de MCF (por exemplo, o reconhecimento das Florestas Comunitárias (FCs) pelo governo, com planos anuais de manejo escritos) ou menos formais/mais tradicionais (por exemplo, nos quais o manejo manifesta-se através de acordos comunitários internos e orais, e/ou ainda sem o reconhecimento do governo). (No caso mais formal, os C\&l deveriam ser vistos como complementação, e não substituição dos planos de manejo escritos). 


\section{0 que são C\&l?}

A sigla C\&l literalmente significa Critérios e Indicadores, mas é usada neste manual, e geralmente também na prática, como uma abreviatura para toda a hierarquia de Princípios, Critérios, Indicadores e Verificadores. C\&l fornecem um meio de reunir sabedoria, conhecimento, informação e dados sobre o MCF nesses quatro níveis de hierarquia, de uma maneira compreensiva, coerente e consistente, que admite verificação. Por serem capazes de criar essas ligações claras, é que C\&l podem tornar-se um instrumento poderoso na busca do objetivo global de manejo florestal sustentável. C\&l podem ajudar a organizar o conhecimento local e científico de tal forma que podem ser usados como uma "forma de verificação da saúde" da floresta e do manejo florestal.

Um conjunto de C\&l bem construído pode:

- expressar o significado do manejo florestal sustentável para a comunidade;

- avaliar o desempenho diante de objetivos predefinidos;

- monitorar os impactos das intervenções de manejo;

- registrar mudanças;

- fornecer diretrizes de ação para o manejo sustentável através da identificação de melhores práticas; e

- adaptar estratégias de manejo com base nas lições obtidas pelo processo acima.

\footnotetext{
${ }^{8}$ Ver também Modelo Genérico de Critérios e Indicadores do CIFOR. A Hierarquia Tropenbos relacionada (similar, mas com uma abordagem um pouco diferente) está bem descrita em Lammerts van Bueren e Blom (1997).
} 


\subsection{Definindo C\&I}

\section{Princípios}

Princípios são afirmações de primeira ordem "verdades fundamentais" ou "leis" - as quais expressam a sabedoria humana sobre o Manejo Florestal Comunitário Sustentável (MFCS).

\section{Princípios são usualmente} expressos como afirmações de ideais.

\section{Exemplos:}

"A integridade do ecossistema é mantida".

"O bem-estar humano é garantido".

Eles se referem a uma função da floresta ou a um aspecto relevante do sistema social que interage com ela, e formam os "abrigos" sob os quais todos os Critérios, Indicadores e Verificadores se encaixam.

\section{Critérios}

Critérios são padrões pelos quais nosso progresso para satisfazer os Princípios pode ser julgado. Eles são reflexões do conhecimento, e adicionam significado ao Princípio e o tornam mais funcional. Os critérios definem o estado ou condições

\section{Critérios são usualmente expressos como um estado ou condição na qual um aspecto da floresta ou região deveria estar, ou como um processo que precisa existir.}

Exemplos:

"As fontes de água são protegidas" "Os produtos florestais contribuem para o bem-estar da comunidade" particulares da floresta ou da comunidade, as quais esperamos encontrar se o Princípio que ele apóia estiver de acordo. Cada Princípio é apoiado por Grupos de Critérios. 


\section{Indicadores}

Indicadores são componentes ou variáveis da floresta ou do sistema de manejo que implicam ou "indicam" o estado ou condições requeridas por um critério. Eles são apresentados como "informação" ou, em outras palavras, como uma mensagem individual significativa

Indicadores são usualmente expressos como algo específico que pode ser avaliado em relação aos critérios.

Exemplos:

"A vegetação ao longo das margens do rio está sendo mantida".

"As famílias recebem benefícios com a venda de produtos florestais".

sobre um componente ou uma variável (e eles são compostos de um ou mais elementos de dados). (Apesar de indicarem circunstâncias que contribuiriam para satisfazer o critério, os indicadores não devem ser entendidos como um conjunto obrigatório de regras ou prescrições).

\section{Verificadores}

Verificadores são dados ou informações necessárias para avaliar um indicador. Eles definem os detalhes específicos que mostram como um indicador é satisfeito.
Verificadores são usualmente expressos com as informações necessárias a serem coletadas.

Exemplos:

"Existência de vegetação contínua ao longo das margens do rio".

"Proporção dos benefícios recebidos pelas famílias derivados da venda de produtos florestais".

\footnotetext{
${ }^{9}$ Em algumas abordagens para C\&l, os verificadores também são definidos como sendo procedimentos necessários para coletar a informação ou dado (isto é, os meios de verificação). Para simplificar, entendemos os verificadores como sendo a informação ou dado necessários, e consideramos que a questão "como" é o "meio" de coletar essa informação ou dado. Esta questão é tratada na seção sobre métodos deste guia. (Seção 3: Desenvolvendo e usando um conjunto de C\&l).
} 


\subsection{Exemplos de C\&l}

O Quadro 1 contém um exemplo extraído do conjunto de C\&l para MCF desenvolvido no teste do CIFOR, na Indonésia. Sua estrutura hierárquica é descrita na Figura 1 . O princípio expressa a compreensão criteriosa da importância do papel das organizações comunitárias (grupos de tomadores de decisão) e instituições (regras, padrões, regulamentos etc.) na garantia da sustentabilidade. Ele é uma expressão de um ideal ou de uma regra fundamental para assegurar a realização do objetivo de MFCS.

Em seguida, três critérios são propostos para apoiar o princípio. Eles definem elementos que dão suporte ao princípio, os quais estabelecem padrões que podem ser medidos ou avaliados pelos indicadores de apoio.

Para cada critério, são determinados vários indicadores. Eles especificam qual informação é necessária para poder inferir se o critério está sendo satisfeito.

Para cada indicador, um ou mais verificadores especificam quais dados ou informações precisam ser checados a fim de ratificar o indicador.

Atenção. Este grupo de exemplos (Quadro 1) foi extraído diretamente do trabalho desenvolvido pela equipe de testes e pela comunidade na Indonésia. $O$ objetivo é que ele ofereça um exemplo de como um conjunto real de $P, C$, I e V se harmoniza em uma hierarquia, mas não atua como um conjunto "modelo" para implementação por outras comunidades. Não somente os $P, C$, I e $V$ necessitariam ser adaptados para outras condições se fossem para ser usados em outro local (como sempre); mas neste caso, os leitores reconheceriam áreas onde os $P, C, I$ e $V$ poderiam possivelmente ser fortalecidos ou esclarecidos para aumentar sua utilidade. Geralmente, não temos feito modificações na linguagem ou qualquer outra mudança no conjunto, a fim de respeitar seu sentido e intenção originais. 
Quadro 1. Exemplo de um Princípio com seus Critérios, Indicadores e Verificadores do MCF desenvolvidos pelo teste do CIFOR, na Indonésia

\section{Princípio}

Instituições sociais locais apóiam (apoiarão) um sistema de uso da terra sustentável.

\section{Critério Um}

A lei costumeira e outros regulamentos asseguram um sistema de uso sustentável da terra.

\section{Indicador}

Existem regras que asseguram o uso sustentável da floresta.

\section{Indicador}

Todos os segmentos da comunidade respeitam a lei costumeira e os outros regulamentos referentes ao sistema de uso sustentável da terra.

\section{Verificadores}

Membros adultos da comunidade conhecem profundamente as leis costumeiras relativas aos sistemas de uso da terra.

As pessoas concordam que as leis costumeiras ainda são eficientes.

Há casos recentes em que punições foram aplicadas.

\section{Indicador}

Há punições para aqueles que não obedecem as regras.

\section{Verificador}

Punições específicas para sistemas específicos de uso da terra.

\section{Indicador}

Há um mecanismo para resolução de conflitos.

\section{Verificadores}

Membros adultos da comunidade podem contar como os conflitos relacionados ao uso da terra são resolvidos.

Há um consenso sobre como o conflito relacionado ao uso

da terra deve ser resolvido.

Casos recentes de resolução tradicional de conflito relacionado ao uso da terra. 


\section{Critério Dois}

A lei costumeira e outros regulamentos asseguram o acesso justo aos recursos naturais da comunidade e a distribuição eqüitativa de seus produtos entre seus membros.

\section{Indicador}

Há regras que asseguram o acesso justo de todos os atores à floresta.

Verificadores

Compreensão clara sobre a composição de atores.

Cada categoria de ator tem acesso à floresta de acordo com a lei costumária e outros regulamentos.

Os atores respeitam a lei costumária e os regulamentos referentes aos recursos florestais.

\section{Critério Três}

A organização social local é capaz de impor o cumprimento da lei costumária e outros regulamentos.

\section{Indicador}

São organizadas reuniões para discutir problemas ambientais e de uso da terra.

\section{Verificadores}

Caso recente de reunião comunitária para discutir sobre problemas ambientais e de uso da terra.

As partes relevantes no conflito estão presentes.

Outros membros da comunidade além das partes em conflito estão presentes.

Há decisões tomadas.

\section{Indicador}

As mulheres têm igual representatividade nas reuniões e decisões.

Verificadores

As mulheres estão presentes nas reuniões.

As mulheres estão envolvidas na discussão.

\section{Indicador}

As decisões são tomadas de maneira participativa.

\section{Verificadores}

As decisões são tomadas em reuniões de membros adultos da comunidade.

Os participantes compreendem o assunto da discussão.

Não há monopólio da discussão por autoridades.

\section{Indicador}

Novos regulamentos e punições que tratam de novos problemas de desenvolvimento relacionados ao uso da terra e aos recursos naturais ainda estão em desenvolvimento.

\section{Verificadores}

As pessoas podem diferenciar entre os regulamentos/regras novos e os tradicionais acordados pela comunidade.

Novos regulamentos/regras são introduzidos localmente. 
Figura 1. Estrutura Hierárquica

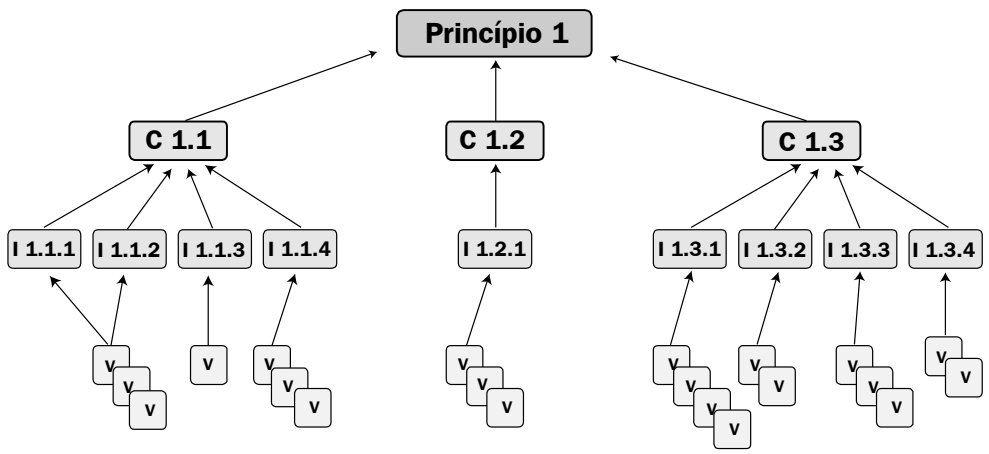

\section{Dicas sobre C\&l:}

- O objetivo global da estrutura hierárquica é criar ligações fortes entre os ideais de primeira ordem (Princípios) e os "sinais" (Critérios e Indicadores) até os pequenos fragmentos de informação na base (Verificadores), de tal forma que a representação criada seja significativa e coerente. Não há nenhum problema em adaptar esta estrutura, ou qualquer outra estrutura de C\&l para satisfazer as necessidades locais, contanto que essa função e lógica básicas permaneçam intactas.

- Mantenha-a factível. Evite a tentação de incluir tudo - tente focalizar nas prioridades, e procure por I \& V efetivos -que, quando possível, harmonizem-se com as práticas atuais (ou fáceis de adotar) de coleta de informação.

- Indicadores freqüentemente parecem se ajustar a mais de um Critério. Ao invés de introduzi-los duas vezes, eles podem ser tratados como indicadores transversais que terão mais de uma finalidade. Da mesma forma para os verificadores - para manter mínima a quantidade de informação que necessita ser coletada e avaliada, alguns Verificadores podem servir a dois ou mais indicadores.

- A linha divisória entre Indicadores e Verificadores pode não ser clara algumas vezes. Como acima, o importante é manter as ligações fortes entre P, C, I e V e não se preocupar muito quanto à terminologia da estrutura hierárquica.

Mais orientações sobre esses pontos são dadas na Seção 3.4. 


\section{Desenvolvendo e usando um conjunto de C\&I}

Esta seção trata do processo de desenvolvimento de um conjunto de C\&l localmente apropriados. Contém um breve resumo de algumas experiências do CIFOR com C\&I para MCF; explora a participação e a colaboração como elementos importantes para a implementação de C\&l, ao mesmo tempo em que destaca uma abordagem possível para usar C\&l baseados na experiência do CIFOR até o momento.

\subsection{Experiência anterior: Resumo da pesquisa de C\&I do CIFOR}

\section{Desenvolvendo e testando C\&I para manejo florestal sustentável em unidades de manejo florestal (comercial)}

Esta pesquisa foi realizada em resposta a uma grande demanda por C\&I consistentes e efetivos em termos de custo de avaliação do manejo florestal para produção de madeira, primariamente para propósitos de certificação. Ela começou desenvolvendo metodologias para testar a relevância e a utilidade de alguns dos conjuntos de C\&l mais aplicados, os quais foram desenvolvidos para a produção de madeira em áreas de floresta natural. Cinco testes de conjuntos preexistentes de C\&l desenvolvidos para avaliar a sustentabilidade do manejo florestal para produção comercial de madeira foram realizados em Unidades de Manejo Florestal (UMFs) na Costa do Marfim, Brasil, Indonésia, Áustria e Alemanha. ${ }^{10}$ Esses testes foram conduzidos por equipes interdisciplinares, envolvidas em testes de campo de C\&l, as

Ver Prabhu et al. (1996). 
quais levaram, cada uma, aproximadamente um mês para finalizar o trabalho.

\section{Desenvolvendo e testando C\&I para $M_{C F}^{11}$}

O CIFOR realizou testes de C\&l apropriados para MFC em três locais: Brasil, República dos Camarões e Indonésia. ${ }^{12}$ Assim como no trabalho com as UMFs, esses testes foram conduzidos por equipes interdisciplinares, cada uma composta de um ecologista, um especialista em manejo florestal e um cientista social.

Para cada teste, um ou dois conjuntos de diretrizes de C\&l para manejo florestal ou manejo de recursos naturais foram selecionados como pontos de partida, juntamente com um ou dois conjuntos de C\&l da Fase 1 do CIFOR. Os conjuntos básicos usados variaram entre os testes. C\&l relevantes de conjuntos básicos existentes (ou diretrizes), juntamente com outros C\&l, foram submetidos a um processo interativo de refinamento. Isso consistiu de quatro revisões chamadas "filtros" (ver Quadro 2) e incluiu testes de campo com a participação das comunidades. As seqüências de filtros ajudaram a fornecer uma nova série de oportunidades para refinar e introduzir novos enunciados e para eliminar $c \& l$ redundantes, comparativamente ambíguos e/ou difíceis ou de aplicação custosa.

\footnotetext{
${ }^{11}$ Ver Burford de Oliveira et al. (1999)

${ }^{12}$ As comunidades envolvidas foram: São Pedro (Rio Arapiuns) e Cachoeira do Maró (Rio Maró), Pará, Brasil; Bedigong e Darok, Distrito de Sanggau, Kalimantan Ocidental, Indonésia; e as vilas de Eyek II e Akak/Bitetele, Arrondissement of Endom, Província Central, República dos Camarões. Nenhum entendimento fornecido pela pesquisa sobre C\&l para MCF do CIFOR, incluindo este manual, teria sido possível sem o esforço e a contribuição dessas comunidades.

${ }^{13}$ Foi difícil encontrar uma variedade de "conjuntos básicos" a serem escolhidos para MCFs. Desta forma, as equipes basearam-se em várias e diferentes fontes, as quais variaram em relevância conforme as equipes e locais. As fontes dos "conjuntos básicos" estão listadas no Apêndice 2.
} 
Quadro 2. Visão geral do "processo de filtragem" de C\&l para MFC das equipes de testes do CIFOR.

\section{Filtro 1.}

Nesta fase inicial, cada membro da equipe selecionou $C \& \mid$ relevantes dentre os Conjuntos Básicos de C\&l que Ihes foram apresentados e propuseram C\&l adicionais que lhe pareceram importantes. Este primeiro processo de filtragem individual resultou em três sub-grupos de C\&l preliminares (um para cada disciplina: ecologia, sócioeconomia e técnicas de manejo).

\section{Filtro 2.}

Este filtro consistiu de uma revisão, feita por uma equipe interdisciplinar, dos sub-conjuntos de $C \& l$ produzidos pelo Filtro 1 . Os membros da equipe estavam cientes de que os conjuntos produzidos durante esse filtro poderiam não tratar de todas as questões que afetam a sustentabilidade de forma crítica nos seus locais de teste e/ou das questões priorizadas pelos membros da comunidade local. Portanto, foi-Ihes pedido que mantivessem essas necessidades em mente até o próximo filtro (que aconteceria no local de teste).

\section{Filtro 3}

O terceiro filtro foi o teste de campo dos $C \&$. Ele foi realizado pelas equipes de teste, que consultaram os grupos florestais de interesse dentro da comunidade local por um período de 10 a 14 dias. Durante os testes de campo, as equipes foram encorajadas a aproveitar sua experiência profissional em Avaliação Rural Participativa (ARP) e outras técnicas para conseguir a contribuição ativa dos membros da comunidade no desenvolvimento e seleção dos C\&l.

\section{Filtro 4.}

O último filtro consistiu no exame dos $C \& l$ pelos participantes durante uma reunião de trabalho (workshop). Pediu-se aos participantes do workshop que avaliassem a aplicabilidade dos C\&l selecionados nas "condições" dos locais de teste, e ao mesmo tempo, mantivessem na memória as características de outro MCF que eles conheciam. 
Embora as equipes de teste tenham encorajado as comunidades dos locais de teste a participarem do desenvolvimento e seleção dos C\&l, a decisão final sobre quais os melhores C\&l, foi dos especialistas da equipe.

A seleção de exemplos dos C\&l resultantes desses testes é apresentada na Seção 4 deste guia.

\section{Trabalho sobre C\&I do CIFOR em desenvolvimento: Abordagens participativa e adaptável}

A experiência adquirida com a participação da comunidade nos três sítios de teste levou o CIFOR a acreditar que no futuro, o desenvolvimento de C\&l para MFCS deverá necessariamente ser baseado em um processo totalmente participativo. As comunidades envolvidas não somente demonstraram possuir uma quantidade significativa de sabedoria e conhecimento sobre suas florestas, como também uma profunda consciência da causa e efeito de tendências e seus impactos na floresta e na própria comunidade. Esse conhecimento e consciência podem ser encontrados na maioria das comunidades que praticam MCF. Partindo-se desse conhecimento, em um processo de troca de experiências, aumento de consciência e de aprendizagem, tanto dentro da comunidade como entre as comunidades e parceiros externos, é possível chegar a uma melhor compreensão, e à concordância sobre o que é necessário para garantir o manejo sustentável dos recursos florestais. Além disso, o objetivo de desenvolver C\&l é implementá-los e usá-los nas tomadas de decisão. Se é preciso que as comunidades se apropriem dos C\&l de forma a poder implementá-los e usá-los nas tomadas de decisão, parece óbvio que as comunidades devam ser os atores-chave em todo o processo, incluindo as fases iniciais. 
No contexto do CIFOR, essa abordagem para C\&l está sendo considerada dentro de um sistema de aperfeiçoamento da colaboração e adaptação no manejo florestal. ${ }^{14} \mathrm{Em}$ síntese, esse sistema enfatiza o potencial possuído por métodos e ferramentas, tais como C\&l, de melhorar o fluxo de informação e troca de aprendizagem entre os atores florestais, de forma a produzir tomadas de decisões melhores e mais justas.

Nas próximas páginas sugerimos alguns princípios básicos de administração do processo participativo baseado nas lições aprendidas durante os testes de C\&l para MCF do CIFOR.

\subsection{Preparando-se para desenvolver e usar C\&l: Perguntas a fazer antes de você começar}

Antes de falar sobre o processo de desenvolvimento de um conjunto de C\&l, é importante tratar de algumas questões tais como as que seguem abaixo, e sentir-se satisfeito com suas respostas para elas.

\section{Quem iniciará e quem estará envolvido neste processo?}

Visto que a participação é a base do processo, é importante esclarecer quais grupos (ou "categorias") de pessoas compõem a comunidade (por exemplo, grupos étnicos, classes sociais, mulheres e homens etc.) - esta questão é tratada mais adiante na seção 3.3 - e identificar os grupos principais de atores de fora da comunidade que precisam ser envolvidos no processo.

Quanto à "equipe" que irá iniciar e/ou facilitar o processo, uma comunidade que está iniciando seu próprio processo de C\&l pode decidir

${ }^{14}$ Esta abordagem faz parte do Programa "Devolução, População Local e Manejo conjunto adaptável". Para mais detalhes, entre em contato com o CIFOR. 
trabalhar independentemente (por exemplo, ter um grupo comunitário que organiza e facilita o processo). Ou, a comunidade pode decidir complementar a informação e/ou habilidades disponíveis convidando outras pessoas ou instituições para apoiá-la. Pessoas de fora da comunidade, por exemplo, podem ajudar com habilidades de facilitação, de identificação de habilidades dos atores ou conhecimento científico ou outros.

Quando o iniciador é uma pessoa ou instituição não pertencente à comunidade - talvez um extensionista ou um Agente Florestal ele deve trabalhar com os membros da comunidade no desenvolvimento e uso de um conjunto de C\&I para MCF, desde que a comunidade apóie fortemente a iniciativa. Caso a comunidade identifique lacunas no conhecimento, o facilitador poderia procurar envolver especialistas dessa área específica para ajudar a corrigir as lacunas.

Um cenário alternativo é possível onde já existem ou poderiam vir a existir vantagens claras na obtenção de colaboração/envolvimento significativo de terceiros. Por exemplo, em uma área de manejo florestal dentro de uma área protegida, que conte com o envolvimento da comunidade, dos gerentes de reservas ecológicas, dos Agentes Florestais ou ONGs. Em tais situações,

\footnotetext{
${ }^{15}$ A abordagem usada pelo CIFOR no desenvolvimento e teste de C\&I foi confiada a uma equipe de "especialistas" em diferentes áreas - geralmente envolveu um engenheiro florestal, um cientista social ou antropólogo, e um ecólogo - os quais iniciaram a seleção de C\&l, e em seguida trabalharam por um curto período com as comunidades. Entretanto, esse processo só foi possível por ter sido iniciado pelo CIFOR (que tinha fácil acesso a essas pessoas) e porque na época isso era desejável, devido à natureza da iniciativa (era uma "iniciativa de pesquisa"). Essa abordagem pode ser difícil de ser aplicada em muitas comunidades iniciadas nos processos, além de muito onerosa e desnecessária ou mesmo indesejável por não ser essencialmente conduzida pela comunidade.
} 
o grupo que está desenvolvendo e usando C\&l poderia incluir tanto a comunidade como os atores-chave de outros parceiros de manejo (ou parceiros potenciais) com capacidade de trazer uma variedade de conhecimento e habilidades apropriadas e complementares. Embora existam obstáculos possíveis, como a dificuldade de conciliar diferentes pontos de vista dos atores, essa abordagem tem potencial para melhorar a colaboração através de um sistema compartilhado de c\&l e, é, provavelmente, mais eficaz em relação aos custos para as comunidades.

Dica: Se possível, pode ser vantajoso incluir um membro de outra comunidade que já tenha experiência no desenvolvimento e uso de C\&l para MCF - ele pode contribuir com observações sobre o processo sob uma perspectiva da comunidade.

\section{Onde se realizará o processo?}

Se você não é um membro da comunidade que planeja usar C\&l em sua própria área, mas está interessado em apoiar o seu desenvolvimento em algum lugar (por exemplo, na situação de uma ONG ou de um funcionário público do setor florestal), verá que a seleção de uma área para implementar C\&l como um instrumento de manejo é outra questão-chave, principalmente se essa for a primeira vez que o processo é tentado. É importante trabalhar onde é bastante provável que se obtenha sucesso. Há probabilidade de a comunidade se interessar? Há boas práticas para servir de exemplo? Os recursos florestais estão razoavelmente intactos? Há incentivos para o envolvimento da comunidade? 


\section{Quais são as condições locais?}

Quais são os idiomas locais na comunidade? Toda a equipe de facilitação/iniciação do desenvolvimento de C\&l é capaz de trabalhar com esses idiomas? Se não, como será feita a interpretação? Quais os níveis de alfabetização na comunidade? Foram identificados métodos participativos adequados para uso com pessoas nesses níveis? Há limitações sazonais sobre quando executar o processo (épocas do ano em que a comunidade está atarefada, épocas quando o acesso é difícil etc.)?

\section{0 grupo de iniciação tem uma "atitude positiva"?}

É vital que o grupo de iniciação (quer sejam todos atores da comunidade, ou atores externos ou os dois juntos) aceite que esse é um exercício de troca de conhecimento. É comum que pessoas com nível educacional mais alto e/ou cientificamente treinadas dominem as discussões no grupo e usem jargões e conceitos de difícil compreensão para os membros da comunidade. Porém, ao invés de ser assim, o grupo de iniciação deve lembrar e enfatizar que é importante a ampla participação dos membros da comunidade, e que todos os participantes necessitarão compreender, apoiar e implementar os C\&l. Os C\&l deveriam ser criados com base no conhecimento, compreensão e habilidades locais. Todos os participantes do desenvolvimento de C\&l estão dispostos a compartilhar seus conhecimentos? Eles estão abertos a novas idéias? As pessoas não pertencentes à comunidade a respeitam e se interessam em aprender com ela? Há desequilíbrio de poder no grupo? ${ }^{16}$ Todos estão dispostos para empregar suficiente tempo no processo?

\footnotetext{
${ }^{16}$ Ver Edmunds e Wollenberg (em desenvolvimento) para uma elaboração teórica, mas que leva em consideração os riscos de negociações entre múltiplos atores, para as comunidades, especialmente onde a abordagem é "neutralizar" ou não enfatizar os diferenciais de poder real entre os participantes, durante o processo de negociação (mas não a longo prazo). Essa consideração e risco certamente também se aplicam ao processo de desenvolvimento de C\&l.
} 


\section{Você tem familiaridade com métodos participativos?}

Como recomendamos uma abordagem totalmente participativa, é vantajoso ter alguém com habilidades em métodos participativos (por exemplo, facilitação). Ou, se você está executando o processo sozinho e, de certa forma, é inexperiente com métodos participativos, seria interessante empregar algum tempo para tomar conhecimento da variedade de ferramentas e métodos participativos que podem ser usados durante o processo. Se esses métodos e ferramentas forem novidade para você, pode ser interessante experimentá-los inicialmente num ambiente conhecido, com o apoio de colegas, a fim de obter habilidades de facilitação e adquirir confiança em administrar processos participativos na prática.

\section{Todos compreendem claramente e concordam quanto aos objetivos do desenvolvimento de C\&l?}

É vital ser claro na fase inicial do processo quanto aos objetivos de desenvolvimento de um conjunto de C\&l para MCF. Esses objetivos, pelo menos os principais, deveriam ser compartilhados (na comunidade e com outros atores, se eles estiverem envolvidos). Baseados nisso, os membros da comunidade deveriam, depois de compreender as vantagens e os custos com os quais irão arcar, desejar ser envolvido no processo. Sem uma compreensão clara dos objetivos globais

\footnotetext{
${ }^{17}$ Há muitos bons recursos para métodos e instrumentos participativos. Ver a seção de referências. Em muitas regiões, é possível obter treinamento no uso de métodos e instrumentos participativos. Ver a lista na seção de referências.
} 
poderá existir uma má vontade justificável, ou uma incerteza em participar, que podem causar decepções no futuro. As questões a serem consideradas neste ponto incluem: Quem tomou a iniciativa de desenvolver um conjunto de C\&l? A comunidade apropriou-se dessa decisão fundamental? Há consenso que é uma boa idéia, e amplo comprometimento com o processo?

A comunidade (e outros parceiros, se apropriado) deverá decidir desde o início de quem serão os C\&l. Questões para refletir incluem: Eles serão criados e usados pela própria comunidade (somente)? Ou eles serão criados e usados pela comunidade em colaboração com outros parceiros (por exemplo, em uma relação de manejo conjunto)? Em ambos os casos, é necessário alguma assistência (por exemplo, facilitadores, pessoas-chave)? Quem será responsável por qual parte do processo? Quem fará o monitoramento? Quem tem direito de usar a informação e como?

\section{Todos compreendem o que acontecerá em seguida?}

Antes de começar a desenvolver os C\&l, todos os atores necessitam entrar num acordo sobre como o processo será organizado, quanto tempo levará, quanto empenho será necessário, e quais serão seus papéis no processo. Comunicar os planos propostos e estar preparado para mudá-los a fim de que sejam adaptados às preferências e limitações da comunidade como um todo (e outros parceiros) ajudará a assegurar um processo funcional. 


\subsection{Definindo os atores: Quem precisa ser envolvido?}

Antes de começar a desenvolver C\&l, é preciso que você estabeleça alguns acordos em comum e comece a trocar conhecimento e a escutar todos os membros da comunidade. Essa é uma grande oportunidade para começar da forma que você pretende seguir com participação total e ativa.

\section{Quem são os atores na comunidade e fora dela?}

É extremamente importante identificar quem na comunidade tem um interesse na floresta, incluindo mulheres, grupos minoritários, jovens e idosos. ${ }^{18}$ Freqüentemente haverá outros atores que não são atualmente membros de fato da comunidade; eles todos deveriam ser pelo menos identificados e idealmente envolvidos em alguma etapa (mesmo apenas sendo informados), apesar de que "como" e "quando" irá variar. Os envolvidos e potencialmente envolvidos precisam estar de acordo sobre quem seriam os atores e como eles devem ser engajados. Quem, por exemplo, será envolvido no desenvolvimento dos C\&l? Quem será responsável pela implementação? Quem fará o monitoramento?

\section{Quais são as estruturas de poder local?}

O manejo envolve o uso do poder para fazer cumprir as decisões. É importante verificar onde se encontra a base do poder na comunidade local. Ela está comprometida com o processo de

\footnotetext{
${ }^{18}$ Há métodos bem elaborados de identificação de atores, incluindo aqueles descritos no Guia Básico de Avaliação (GBA) (Equipe de testes de métodos do CIFOR, 1999) e no manual "Quem é importante? (Colfer et al. 1999) da série manuais de C\&l do CIFOR, bem como o Tree and Land Tenure Rapid Appraisal Tools da FAO (Freudenberger, 1994). Ver seção de referências para detalhes.
} 
C\&l? Você pode garantir que os menos poderosos (por exemplo, mulheres, grupos minoritários, idosos) possuem uma "voz" clara no processo de desenvolvimento dos C\&l? Há outras bases de poder fora da comunidade que precisam ser consideradas? Existem algumas ferramentas muito úteis e amplamente disponíveis que também poderão ajudar nesta identificação.

\section{Quem faz o que, onde e quando?}

No início do processo é importante estabelecer os limites da paisagem florestal e até onde se estende a influência da comunidade (em muitos casos isto não é claramente definido ou não existe consenso). Também é importante estabelecer quais as principais atividades na área e quem as realiza.

Há muitas técnicas que, bem praticadas, irão identificar e mapear os limites do recurso florestal e estabelecer quem usa os recursos, para que, por que e quando. ${ }^{20}$ Exercícios de mapeamento participativo e a criação de calendários de atividades podem ser divertidos, e envolver muitas pessoas no processo, além de fornecer uma maneira excelente de estabelecer trocas de percepções da situação corrente.

\footnotetext{
${ }^{19}$ Ver por exemplo, Tree and Land Tenure Rapid Appraisal Tools da FAO (Freudenberger, 1994), particularmente o mapeamento social com Diagramas de Venn, para uma abordagem participativa que identifica as estruturas do poder. Ver a seção de referências para mais detalhes.

${ }^{20}$ Ver, por exemplo, Community Toolbox da FAO, manual 14 (Case 1990) e Tree and Land Tenure Rapid Appraisal Tools da FAO (Freudenberger, 1994), particularmente mapas, transectos e calendários. Ver seção de referências para detalhes.
} 


\subsection{0 ponto de partida para C\&l: Conjuntos básicos, padrões ou visões?}

Agora que todos têm uma boa idéia de quem fará o quê e onde, como a comunidade opera coletivamente e quem são os atores, como iniciar o desenvolvimento de um conjunto de C\&l? Não há nenhuma resposta certa e simples para essa questão. Dependerá muito da amplitude dos objetivos, e será necessário ser sensível às visões da comunidade e de outros parceiros. Aqui sugerimos três opções que são pontos um amplo espectro de possíveis "pontos de entrada" no processo de desenvolvimento de C\&l.

\section{Comece com um conjunto de C\&I desenvolvido por outra pessoa}

Isso pode parecer "fraudulento" mas é de fato um ponto de partida bem reconhecido e recomendado pelo CIFOR em suas Diretrizes de Desenvolvimento, Teste e Seleção de C\&. ${ }^{21}$ Grande parte do trabalho envolvido no desenvolvimento de C\&l consiste em mudar e modificar um conjunto básico de C\&l para que ele se torne continuamente mais apropriado e relevante para as circunstâncias locais. 0 trabalho de outras pessoas que já se envolveram nesse processo pode ajudá-lo a economizar muito tempo e servir de boa fonte de memória e de idéias. Ter um bom exemplo de conjunto de C\&l pode ser de grande ajuda para encorajar todos a tomarem conhecimento e se familiarizarem com os conceitos. Um ponto de partida útil poderia ser o conjunto genérico de C\&I do CIFOR ${ }^{22}$ ou exemplos do estudo de caso de C\&I para MCF na Seção 4 deste guia.

\footnotetext{
${ }^{21}$ Ver Prabhu et al. (1998)

${ }^{22}$ Deve-se notar entretanto, que este conjunto foi elaborado para uma unidade de manejo florestal comercial, e dessa forma, com abordagens de sustentabilidade com perspectivas um pouco diferentes. Ver Série Manuais de C\&l do CIFOR, Manual No. 2 (Equipe de C\&l do CIFOR, 1999).
} 
Contudo, iniciar com um conjunto de C\&l de outra pessoa também tem desvantagens. Primeiro, os C\&l necessitarão de mudanças, pois certamente incluem muitas palavras e idéias que são muito específicas da área onde foram desenvolvidas, e por isso não serão relevantes no local em que você está trabalhando (ou no caso do conjunto genérico do CIFOR - que é intencionalmente geral, e assim necessita de adaptação para o local específico). Esses pressupostos ou preconceitos embutidos nos conjuntos básicos afastam as pessoas e podem dar muito trabalho para serem alterados ou removidos. Além disso, a maioria dos conjuntos de C\&l disponíveis foi desenvolvida por "cientistas ou técnicos", e dizem respeito principalmente ao manejo comercial de florestas, e portanto podem não ser totalmente relevantes.

\section{Inicie com um padrão}

Alguns países estão desenvolvendo seus próprios padrões nacionais de manejo florestal sustentável, e esse pode ser um ponto de partida. O conteúdo de tal conjunto padrão é, provavelmente, amplamente relevante para o local e, se apropriado, pode ser incluído no nível de Princípios e Critérios. Todavia, o padrão pode não ser direcionado ao manejo comunitário de florestas, (particularmente se ele for elaborado para regular a indústria madeireira ou o manejo de plantações industriais). Também pode não estar bem estruturado hierarquicamente.

Outras fontes de conjuntos de C\&l são de corporações tais como o Conselho de Manejo Florestal (mais conhecido pela sigla FSC - Forest Stewardship Council), ${ }^{23}$ que os usa na certificação de produtos florestais. Se a comunidade tem pretensão de certificação, então esta pode ser uma fonte apropriada para começar. As empresas

\footnotetext{
${ }^{23}$ Ver seção de referências.
} 
e outras organizações que oferecem serviços de certificação e que avaliam as práticas de manejo florestal podem fornecer exemplos de seus modelos (conjuntos de C\&l) que têm sido modificados considerando as condições locais similares às da comunidade.

\section{Comece a partir da visão da comunidade sobre manejo florestal sustentável}

A terceira abordagem requer o uso de uma folha de papel em branco para esboçar um conjunto de C\&l a partir da comunidade, construindo uma visão local comum do manejo sustentável da floresta, e esboçando o conjunto de C\&l conforme o conhecimento e percepções locais. Se mais parceiros forem envolvidos, eles também podem construir visões para serem comparadas e fundidas até o ponto em que se tornem compatíveis.

A experiência do CIFOR nos três locais de teste demonstrou com bastante clareza que o conhecimento local era sensato e confiável. As relações íntimas e de longo prazo das pessoas com a paisagem florestal, bem como sua dependência da floresta, as tornou sensíveis às mudanças e as capacitou a identificar ligações entre as diferentes causas e efeitos. Além disso, elas geralmente estavam bastante conscientes do impacto de suas próprias intervenções e das intervenções de outros.

Começar a partir da visão da comunidade sobre manejo florestal sustentável pode ter a vantagem de garantir que os C\&l pertençam totalmente à comunidade, sejam percebidos exclusivamente como produto de seu próprio conhecimento e pensamento, e possam ser usados pela comunidade. No teste de C\&l na República dos Camarões, a equipe verificou como foi estimulante e significativa a ajuda resultante de uma série de encontros nos quais a comunidade identificou e depois classificou suas prioridades para sua floresta a fim de identificar Princípios e Critérios para o manejo sustentável. 


\subsection{Desenvolvendo C\&l: Algumas etapas práticas}

(Ver Seção 4. Conteúdo de C\&l para exemplos práticos de P, C, I e V)

\section{Preparação básica}

Uma vez identificados os atores (se somente a comunidade ou a comunidade e outros atores), como foi explicado nas seções anteriores deste guia, é preciso fazer uma preparação básica para o desenvolvimento de C\&l. É necessário estabelecer um acordo em termos gerais sobre o objetivo do manejo florestal sustentável e sobre o compromisso para testar C\&l como uma ferramenta. Isto pode ser feito por meio de uma combinação de reuniões com indivíduos e em grupos, como for mais apropriado.

\section{Aprenda sobre a estrutura e conceitos dos C\&I}

A próxima etapa é certificar-se de que todos os atores conhecem e estão satisfeitos com os C\&l. Deve-se organizar um encontro para examinar os conceitos e explicações de C\&l descritos na Parte 2 deste guia. Certifique-se de que todos entendem o significado dos diferentes níveis dos termos Princípio, Critérios, Indicadores e Verificadores. Nos três locais de teste observamos que muitas pessoas não tiveram nenhuma dificuldade em compreender o significado de Princípios e Indicadores, porém, a compreensão do significado de Critérios foi mais difícil.

\footnotetext{
${ }^{24}$ Deve-se notar que o CIFOR ainda não testou completamente essa abordagem em campo, como descrita aqui. A abordagem é desenvolvida a partir de uma compilação dos testes e experiências de campo e de reflexões, os quais baseiamse tanto no próprio trabalho do CIFOR como nas lições de outras comunidades e seus parceiros.
} 
Examine isto com bastante atenção, para obter a maior compreensão possível antes de passar para a próxima etapa.

Dica: Lembre-se de concentrar sua atenção em tornar a estrutura útil e satisfatória para as pessoas que estarão monitorando e usando os C\&l. 0 importante é compreender o significado que está por trás de um conjunto de C\&l e não os termos atualmente usados. Se os participantes acharem que é mais conveniente compreendê-los usando termos como "ideais", "objetivos", "indicadores" ou "sinais" e "informações", ou outra coleção de termos, podem fazê-lo. 0 importante é que haja uma completa compreensão da importância das ligações entre os níveis -aquelas coisas que podem ser medidas ou monitoradas ("indicadores") e ligadas diretamente aos padrões sobre as condições ou processos ("critérios"). Estes, por sua vez, contribuem diretamente na construção das expressões das "verdades fundamentais" ("princípios"). É possível até mudar a estrutura da hierarquia para satisfazer as necessidades locais, contanto que esse tipo de lógica fundamental permaneça intacta.

\section{Desenvolva os princípios}

Depois que os participantes já compreenderam as diferenças entre Princípios, Critérios, Indicadores e Verificadores, o próximo passo é identificar os princípios de primeira ordem, ou ideais. Esta etapa pode começar com a promoção de uma série de encontros para antever e estabelecer o que o manejo sustentável da floresta significa para os diferentes atores.

Questões para serem levantadas nos encontros podem incluir por exemplo:

- O que gostaríamos de ver como um futuro ideal para nossa comunidade e nossas florestas?

- Quais os elementos essenciais dessa visão do manejo sustentável? 
- Quais as nossas prioridades para a floresta e nossa comunidade? (Para que o conjunto de C\&l possa ser mantido pequeno).

- Como classificar essas prioridades em ordem de importância?

- Como podemos expressar essas prioridades em Princípios?

- Se começamos utilizando um conjunto de Princípios existente, eles foram entendidos? As pessoas concordam com esses princípios? Eles deveriam ser modificados?

É importante lembrar a definição de Princípios dada na Parte 2 deste guia. 0 objetivo é chegar a um número reduzido de princípios ou ideais básicos (3 ou 4).

\section{Desenvolva os Critérios}

A próxima etapa é identificar um número de critérios ou "pilares" que sustentam cada princípio. Isto pode ser feito no mesmo encontro ou em encontros subseqüentes, como for mais adequado.

Os itens a serem tratados poderiam incluir, para cada Princípio:

- O que é preciso avaliar para saber se o Princípio está sendo respeitado?

- Como reconhecer uma floresta manejada sustentavelmente?

- Como reconhecer um bom manejo comunitário?

- Como podemos expressar estas informações como critérios?

- Se começamos utilizando um conjunto de critérios existente, eles foram entendidos? As pessoas concordam com eles? Eles precisam ser modificados? 
As respostas para tais questões podem definir os "resultados observáveis" das práticas de manejo sustentável, descrevendo as condições ou aspectos desejados na floresta, ou na comunidade, ou nos setores político/econômico. Outras respostas podem definir os processos que precisam ser adequados para que se consiga manejar a floresta de acordo com os Princípios. 0 objetivo aqui é chegar a um número de Critérios (3 ou 4) para cada Princípio.

\section{Desenvolva os indicadores}

Tendo identificado os Critérios essenciais que necessitam ser avaliados para cada Princípio, a próxima etapa é proceder identificando os indicadores a serem usados para julgar se os Critérios estão sendo satisfeitos. Esses Indicadores deveriam conter informações reais que possam ser medidas de alguma maneira.

As questões para ajudar a desenvolver indicadores podem incluir:

- O que precisamos saber para avaliar cada critério?

- Quais desses indicadores são mais importantes e mensuráveis?

- Podemos expressar estas informações como indicadores?

- Se começamos utilizando um conjunto de Indicadores existente, quais deles podemos utilizar? Quais deles precisamos mudar?

O objetivo é definir um número reduzido de indicadores-chave (2 ou 3) para cada Critério, os quais possam ser medidos ou pontuados de alguma maneira que permita a avaliação dos Critérios a ser feita.

\section{Desenvolva os Verificadores}

Tendo identificado os indicadores, será necessário identificar os verificadores que descrevem os verdadeiros dados ou informações necessários para os indicadores. 
Considere cada indicador e formule questões tais como:

- Quais são os diferentes tipos de dados que poderiam dizernos isso? 0 que precisamos contar, medir, observar e registrar?

- Quais são os poucos dados-chave que irão nos dizer isso?

O seu objetivo global é tentar desenvolver um conjunto mínimo de C\&lchave, que seja amplo o bastante para incluir todas as questões importantes, mas pequeno o suficiente para ser útil. Estabelecer bons indicadores-chave reduzirá a quantidade de dados a ser coletada.

\section{Dicas:}

- $\quad$ Se você identificou quatro Princípios, cada um com três Critérios, os quais por sua vez possuem três Indicadores, haverá um total de 36 Indicadores que precisarão ser monitorados e avaliados. Isto é aproximadamente o que vai acontecer na primeira tentativa. Não tente incluir tudo e não espere alcançar rapidamente a perfeição. Como você verá a seguir, haverá outras oportunidades para refinar e melhorar o conjunto de C\&l a partir da experiência. Mantenha-o simples.

- Para manter mínimo o esforço envolvido, tenha em mente que as informações existentes já estão disponíveis ou de forma avançada, e que as atividades em andamento fornecem informações. Desde que seja razoável (isto é, que satisfaça suas necessidades e que se adeque de forma lógica à estrutura), tome como base o que já existe!

(O outro lado da questão é que esse processo pode revelar que algumas das informações que já estão sendo coletadas não são especialmente úteis ou eficientes. Isso pode ser tornado mais eficiente?) 


\section{Desenvolva métodos de coleta de dados para os Verificadores}

Para completar esta fase você também precisa definir como, onde e quando os dados para os Verificadores poderiam ser obtidos. Alguns dados, por exemplo, podem ser obtidos através de observações diretas no campo. Outros, podem ser obtidos através de algum tipo de levantamento ou acesso a registros existentes. Pode ser necessário usar um método participativo ou um método de avaliação para obter outras informações. 0 objetivo aqui é definir de onde virão as informações e os dados, e como você irá obtê-los. Isso não fornecerá apenas um guia inicial para uso posterior; mas apontarão sinais precoces de alerta para verificadores que podem ser muito difíceis de se medir, ou com custos de mensuração incompatíveis.

Para cada Verificador, as questões sobre métodos podem incluir:

- Onde podemos obter os dados?

- Como eles podem ser coletados?

- Qual a freqüencia com que os dados precisam ser coletados para serem úteis?

\section{Dicas:}

Em todas as etapas do desenvolvimento de C\&l, assegure-se de que:

- $\quad$ O objetivo de cada etapa esteja claro;

- As pessoas ainda se lembram das diferenças entre Princípios, Critérios, Indicadores e Verificadores ou de quaisquer termos que estão sendo usados;

- Tudo foi registrado; e

- $\quad$ Alguém do grupo registre o tempo, mantenha o grupo enfocado nas tarefas, e garanta que todos se sintam capazes de participar da discussão (isto é, ter um facilitador pode ser uma boa idéia). 


\section{6 "Filtrando" os C\&l: Eles são os melhores para o trabalho?}

A próxima etapa é filtrar os $C \& l$ - isto significa examinar um por um com o grupo, para verificar se eles são:

- Indicadores-chave - o objetivo não é obter o máximo de informação possível, mas identificar o número-chave mínimo de critérios e indicadores que fornecerão informação suficiente para avaliar o progresso em direção à meta do manejo sustentável. Este conjunto Ihe dará informação sobre o que você precisa saber?

- Fáceis e possíveis de detectar, registrar e interpretar - é preciso garantir que a aplicação dos $C \& l$ e a coleta dos dados sejam viáveis, e que a informação seja registrada de tal maneira que possa ser julgada ou interpretada. Você pode fazer isto com as habilidades que já possui ou poderia razoavelmente obtê-las? Você pode conduzir os métodos? Como acima, você pode minimizar o esforço extra tomando como base práticas ou atividades existentes, sempre que isso for razoável e útil?

- Confiáveis - é necessário estar seguro que os C\&l escolhidos fornecerão informações confiáveis e consistentes. Quaisquer duas pessoas obterão as mesmas respostas se usarem os mesmos C\&l no mesmo local?

Pelo fato de os C\&l terem sido desenvolvidos para uso da comunidade, também é necessário examinar os C\&l para estar seguro de que eles são:

- Aceitos pelo maior número possível de atores da comunidade;

- Facilmente compreendidos pelos membros da comunidade;

- Compatíveis com as habilidades da comunidade; e

- Eficientes quanto ao uso do tempo 
Se o grupo julgar, através da análise (filtragem), que alguns Princípios, Critérios, Indicadores ou Verificadores não são adequados então, é hora de buscar alternativas!

\subsection{Primeiro teste: Fazendo uma avaliação rápida dos C\&I}

Antes de desenvolver um plano de monitoramento e avaliação completo e colocar os C\&l em uso no campo (Seção 3.8), uma próxima etapa possível é "testar" a utilidade do conjunto de C\&l desenvolvido, usando-o diretamente como base de uma autoavaliação participativa rápida. Isso pode ter as vantagens de:

- Introduzir o conjunto de C\&l temporário para uma ampla variedade de atores;

- Revelar lacunas, inconsistências e equívocos referentes ao conjunto de C\&l; e

- Revelar como os atores percebem a sua situação e desempenho antes que o monitoramento comece a "todo vapor".

Uma avaliação rápida pode ser feita listando todos os indicadores numa folha de papel grande e, para cada um deles, perguntar "Como estamos fazendo?". Se a resposta é "bem", "mal" ou "mais ou menos", você pode registrá-la com sinais simples tais como uma lua cheia para "bom", lua nova para "mau" e uma meia lua para "mais ou menos". Outra maneira de fazer esta "classificação" é com círculos de papel adesivo - círculos verdes para "bom", círculos vermelhos para "mau" e círculos amarelos para "mais ou menos". Para os indicadores que requerem medições e monitoramento durante um período de tempo, tudo o que você pode fazer é estimar ou supor - isso é suficiente. 0 monitoramento correto virá depois. Nesta etapa você está apenas tentando obter uma "percepção" geral da situação. 
Essa é uma boa oportunidade para participação. Pode ser muito revelador se muitos grupos de diferentes pessoas da comunidade fizerem uma avaliação como essa separadamente, para em seguida comparar seus resultados. Deve-se esclarecer que o propósito desta avaliação é tentar obter idéias sobre como melhorar a situação. Assim, os indicadores que não obtiverem classificação "bom" devem ser vistos não como problemas, mas como oportunidades para aperfeiçoamentos.

Aqui está uma maneira simples de conseguir uma rápida visão geral de sua "avaliação da sustentabilidade":

- Começando com sua Avaliação Rápida, dê uma pontuação 3 para as luas cheias, pontuação 2 para as meia luas e pontuação 1 para as luas novas.

- Para cada Critério some todas as pontuações dos Indicadores e divida pelo número total de Indicadores sob aquele Critério. Atribua os resultados ao Critério apropriado.

- Some as pontuações para cada Critério sob cada Princípio e divida pelo número total de Critérios para cada princípio. Atribua os resultados ao Princípio apropriado.

(Você também pode fazer isto no nível de Princípio para obter uma classificação individual de 1 a 3 . Some as pontuações totais dos Princípios, e divida pelo número de Princípios; embora neste nível de supersimplificação o resultado não seja especialmente significativo. De qualquer forma você terá uma indicação (super-simplificada) de quão próxima está a meta geral do manejo sustentáve. ${ }^{25}$ )

\footnotetext{
${ }^{25}$ Uma abordagem mais sutil, embora complexa, é ponderar cada elemento. Ver as publicações "Guia de Pontuação" da série manuais de C\&l do CIFOR e "The MCA Manual" para mais idéias. (Salim et al. 1999 e Mendosa et al. 1999).
} 
A parte mais importante e interessante disso é fazer comparações entre os Princípios, Critérios e Indicadores para enfatizar os aspectos nos quais você está progredindo, e aqueles onde você percebe uma necessidade de melhoria. Há tendências e padrões? Por que?

\section{Idéias para ação imediata provenientes da avaliação rápida}

Primeiro, a partir das tendências e padrões que você já explorou, determine os possíveis assuntos fundamentais a serem tratados, e discuta-os. Discuta que ações poderiam ser tomadas para alterar as avaliações de luas novas ou meia luas para luas cheias? (Às vezes, há boas idéias sobre "melhores práticas" embutidas nos C\&l-observe-os, procure as idéias). Para toda ação proposta, determine se ela deve ser executada, por quem e como.

Segundo, retorne ao seu conjunto de C\&l e examine se a avaliação rápida revelou alguns problemas tais como termos que não estão claros ou aspectos que não podem ser mensurados. Se isto acontecer, comece uma readequação agora, melhorandoos enquanto a experiência está no início, antes do monitoramento de longo prazo.

\subsection{Monitoramento: Colocando os C\&l em prática}

A próxima etapa envolve colocar em prática os C\&l, planejando e implementando um sistema de monitoramento para os mesmos que reabasteça o sistema de manejo. Os C\&l são muito empregados por certificadores de produtos florestais, como um sistema para avaliar se os produtos foram obtidos por meio de práticas de manejo florestal sustentável. Essas avaliações são freqüentemente formais e, em alguns casos, até muito rigorosas - envolvem coleta e análise de uma grande 
quantidade de dados. Geralmente elas são executadas por certificadores profissionais externos. A que estamos propondo aqui é algo mais direto e agradável para o usuário, e essencialmente participativa.

Abaixo sugerimos uma série de etapas que seu conjunto de C\&l irá percorrer até assegurar o manejo florestal sustentável. Nem todas as etapas serão apropriadas para todas as situações, mas elas devem fornecer algumas idéias que permitirão avançar e aproveitar o esforço empreendido no desenvolvimento dos C\&.

As etapas abaixo formam um anel ou ciclo de planejamento, ação, monitoramento, avaliação e aprendizagem a serem realizados pela comunidade na execução de um processo (esperançosamente, em constante melhora).

\section{Etapa 1: Elaboração de um plano de monitoramento}

Você precisará elaborar um plano de monitoramento para organizar os próximos estágios e para que todas as pessoas envolvidas saibam o que irá acontecer. Para cada Verificador ${ }^{26}$ pergunte:

- Será monitorado?

- Por quem?

- Quando?

- Como?

- Quem é o responsável por colocar os resultados agrupados?

- Como os resultados serão registrados?

- Quando deverá ser feita a avaliação?

- Que recursos serão necessários (tempo, dinheiro, ferramentas ou outros equipamentos, acesso a informação)?

\footnotetext{
${ }^{26}$ Como mencionado anteriormente, em alguns casos há uma justaposição direta entre Indicador e Verificador - se esse for o caso, então obviamente esta etapa ocorrerá no nível de Indicador, como apropriado.
} 
Para cada indicador, procure manter a necessidade de informação o mais simples possível. Tente dividir a responsabilidade pelo monitoramento por toda a comunidade, e entre os parceiros. Isso envolve a participação de mais pessoas e reduz a carga de trabalho para todos. Nossa experiência indica que o conhecimento não é disseminado igualmente entre todos os atores. Identifique quem tem mais conhecimento sobre os diferentes aspectos compreendidos pelos C\&l. Convide essas pessoas para se responsabilizarem pelo monitoramento da informação com a qual estão familiarizados.

Não esqueça: 0 monitoramento deve ser elaborado o mais próximo possível das habilidades existentes, e também das atividades formais e informais existentes dentro da comunidade.

Pense sobre o cronograma total. Quando o primeiro programa de monitoramento e avaliação deve ser executado? Você realizará imediatamente um exercício de monitoramento? Quando o primeiro conjunto completo de resultados estará pronto? Você está iniciando um programa de monitoramento que continuará por muitos anos?

Você deve planejar como reunir toda a informação a ser coletada. Isso é essencialmente importante. Quem será responsável por agrupar todos os resultados? Será uma pessoa ou um grupo? Todos os envolvidos no monitoramento sabem como fornecer sua informação para essa pessoa ou grupo? Quando eles devem fornecer a informação? Todos se sentem satisfeitos em fornecer informação para essa pessoa ou grupo? Se não, talvez você deva pensar novamente sobre quem deveria ser essa pessoa. Ela é membro da comunidade e, se não for, há realmente uma boa razão para isso? A apropriação do monitoramento pela comunidade é muito importante. Manter o centro de informações dentro da comunidade tornará as informações mais disponíveis, sendo muito mais provável que sejam usadas do que se forem 
mantidas em um escritório distante. Recomendamos que entre o início do monitoramento e o agrupamento das informações, não decorra mais do que um ano.

Observe a necessidade de recursos. Eles estão disponíveis ou podem tornar-se disponíveis? Se não, ajuste seus planos.

Pode ser uma boa idéia organizar um calendário que determina claramente a data em que o monitoramento deve ser realizado. É possível que algum monitoramento precise estender-se por um certo período. Outros elementos do monitoramento podem ser agrupados em uma época específica. Identifique quem é que vai fazer o quê, esclarecendo quando a informação deve ser coletada, quem irá colocá-la agrupada, e quando será realizada a próxima avaliação. Tenha certeza que todos na comunidade estão cientes disso.

\section{Etapa 2: Criação de um plano de avaliação}

Você também precisa planejar a fase de avaliação.

- Como os resultados do monitoramento serão usados?

- Quem realizará a avaliação?

- Como o processo e os resultados serão mantidos transparentes e acessíveis para toda a comunidade?

- Como os resultados serão apresentados para os atores?

- Que tipos de decisão serão tomadas a partir desses resultados?

- Por quem? Como manter o processo eqüitativo e participativo?

- Quem decidirá sobre as novas ações que devem ser empreendidas como resultado da avaliação? 


\section{Etapa 3: Monitoramento}

Havendo um acordo sobre o plano, ele precisa ser executado - execute-o!

\section{Etapa 4: Avaliação dos resultados}

Todos os resultados do monitoramento devem ser agrupados no tempo acordado. Esse é um novo momento para reflexão. Diga aos monitores e/ou a um grupo de atores-chave para fazer uma avaliação e um registro preciso dos resultados (não apenas pontuações, mais as questões-chave que emergem das discussões). Use o sistema de pontuação simples usado na primeira avaliação rápida, ou um sistema modificado baseado no que você aprendeu dessa experiência. Se for preciso usar um sistema de pontuação novo ou modificado, você ainda pode fazer uma comparação com a avaliação anterior? Este é um ponto importante a ser considerado todas as vezes em que for feita uma avaliação.

Uma possibilidade adicional desta etapa é a realização de outro exercício de participação, envolvendo uma grande variedade de atores. Faça com que eles pontuem os indicadores usando o mesmo sistema de pontuação usado pelos monitores. (Isto é o mesmo que fazer uma avaliação rápida; seu objetivo é oferecer perspectivas adicionais e dar informações sobre os C\&l). Compare os resultados desse exercício com os resultados produzidos pela equipe de monitoramento. Eles diferem? Troque conhecimento e experiências e discuta as diferenças de percepção. Isto pode expor problemas com os métodos de monitoramento, e neste caso você pode alterar o processo no futuro.

Questões a serem consideradas no processo de avaliação incluem:

- Como parece o quadro geral em termos de sustentabilidade? Geralmente positivo, negativo ou no meio? 
- Você pode verificar alguns padrões ou tendências onde observam-se pontos fortes e fracos? Por que eles existem?

- Existe algo que seja particularmente crítico ou preocupante? Particularmente positivo? Por que?

- Se você já fez uma avaliação rápida anteriormente, como estas se comparam? O que permanece igual, o que mudou? Qual melhorou ou piorou?

- Observando no nível de Critério ou Indicador - por que cada um obteve essa pontuação? (Por que esse indicador ou critério sofreu alteração em relação à avaliação anterior?) Que fatores contribuem para a avaliação ou mudança que estão sob o controle da comunidade e/ou parceiros? Que fatores estão atualmente fora do controle da comunidade ou parceiros? As causas dos resultados ou mudanças são desconhecidas? Há uma forma de descobrir?

\section{Dicas:}

- As "negativas" nas avaliações não são "fracassos" - elas são oportunidades para aprendizagem.

- Os "sucessos" também são oportunidades de aprendizagem - e não esqueça de celebrá-los. Há alguma maneira da comunidade/ parceiros serem recompensados pelo progresso?

- Não se esqueça de registrar claramente os resultados da avaliação, de uma forma que faça sentido para as pessoas que não participaram da discussão. Distribua esse registro para os membros ou atores da comunidade que não estavam diretamente envolvidos na avaliação.

Há uma boa maneira de representar visualmente os resultados de avaliações ao longo do tempo. É por meio dos "Diagramas em 
forma de teia de aranha" (Ver Figura 2 a seguir) ${ }^{27}$. Isso envolve a criação de uma imagem como a de uma teia de aranha, ou uma roda de bicicleta com seus raios (achatada dos lados), e designando a cada um dos raios um tema do conjunto de C\&l (usualmente no nível de Critério). Considerando que o centro exato tem um valor zero (isto é, muito insatisfatório), e a borda de fora tem um valor 10 (excelente), as pontuações aproximadas de cada

Figura 2. Exemplo de um diagrama em forma de teia de aranha

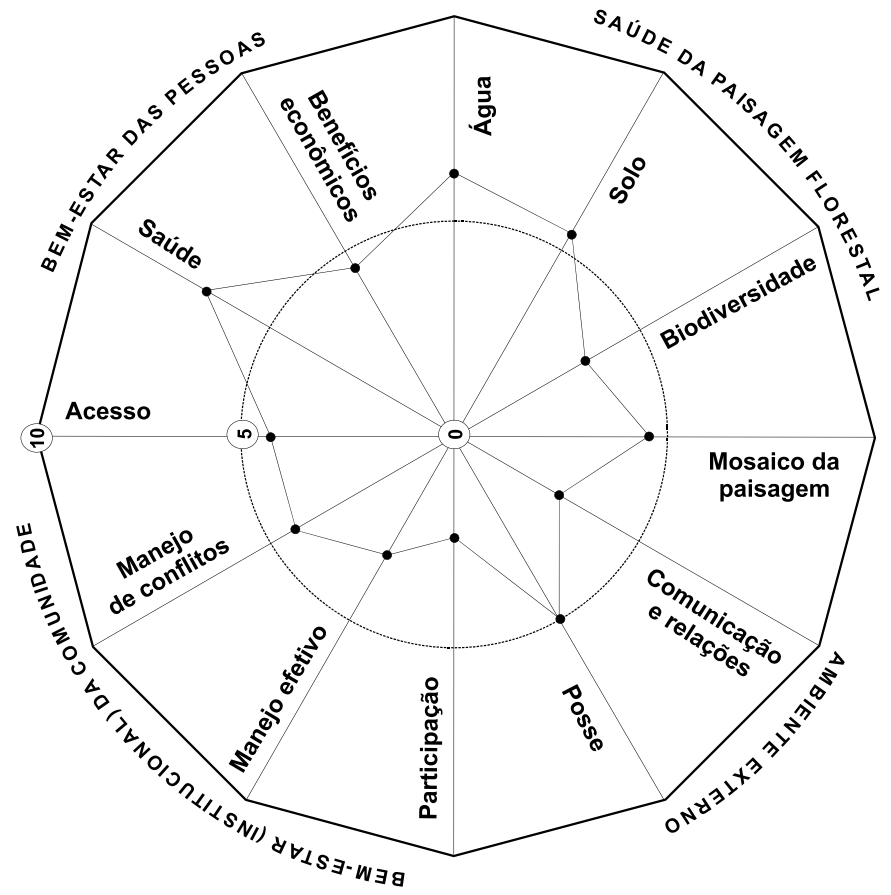

${ }^{27}$ A inclusão dessa ferramenta foi inspirada pelos "Polígonos de Sustentabilidade" encontrados em Herweg et al. (1998) e pela realização de projetos tais como o Projeto Manejo de Recursos em Comunidades do Nepal-Austrália e o projeto Floresta Comunitária do Nepal- Reino Unido, nessa área. 
Critério podem ser marcadas nos "raios" ou "teias de aranha". Quando uma linha é traçada ligando todas as pontuações, surge uma imagem que apresenta as tendências das áreas "fortes" e "fracas". Isto não é útil somente em uma avaliação individual, mas também para fornecer uma imagem das tendências de mudança na sustentabilidade ao longo do tempo, caso seja repetida todos os anos.

\section{Etapa 5: Novo plano de ação}

A criação de um novo plano de manejo está fortemente ligada à etapa de avaliação descrita anteriormente - esta etapa pode inclusive ser realizada na mesma reunião ou reuniões, pois ela vai ser desenvolvida diretamente a partir da aprendizagem adquirida no processo de avaliação. Especificamente, esta etapa examina a relação entre as ações de manejo anteriores e as atuais, realizadas pela comunidade e outros parceiros e seu resultado (isto é, o último item da etapa 4), e considera que ajustes ou mudanças podem ser feitos no futuro.

Novamente, no nível de Critério (ou Indicador se funcionar melhor), o grupo de avaliação ou de manejo tem que considerar, detalhadamente, a avaliação dos resultados em relação às ações de manejo (ou ausência de ações). Se você tem um tempo limitado, ou uma grande quantidade de C\&l, pode ser preciso priorizar aqueles que são mais importantes em uma discussão de grupo.

Algumas questões que ajudam no processo de aprendizagem incluem:

- Que ações no manejo (ou ausência de ações) influenciaram o Critério ou Indicador?

- Foram observadas ligações diretas entre as ações e os efeitos (isto é, que efeitos das atividades de manejo foram "positivos" ou "negativos")? Houve alguma surpresa? Por que?

- Há alguma lacuna no conhecimento sobre por que as coisas estão acontecendo? Como elas podem ser preenchidas? 
- Considerando todos os pontos acima, as atividades anteriores de manejo local devem continuar ou mudar? Há novas ações que possam ser empreendidas para lidar com as questões que os Indicadores demonstram ter desempenho baixo ou em declínio?

- Há qualquer outra idéia para ação surgida dos resultados de monitoramento e avaliação? Como essas idéias podem ser executadas?

- O que mais (além do manejo local) contribuiu para os efeitos? Se houver quaisquer influências externas que estejam afetando de forma crítica e negativa a sustentabilidade, elas podem ser tratadas? Se essas influências estavam fora do "controle" desse grupo, elas ainda estão? Alguma coisa pode ser feita para transformar positivamente essas influências externas?

\section{Etapa 6: Modificação do conjunto de C\&I}

O conjunto original de C\&l não é sagrado - ele deve existir, crescer, mudar e evoluir, refletindo o conhecimento da comunidade e também as mudanças na terra e no meio ambiente.

Como resultado de todo o trabalho feito até aqui, deve-se esclarecer que alguns dos conjuntos de $C \& l$ iniciais podem não estar correspondendo à expectativa. Eles podem ser difíceis de monitorar, ou seus resultados serem ambíguos, ou ainda podem conter problemas sem solução no momento. Se for assim, desista deles!

Você também deve observar que surgiram algumas idéias novas, as quais podem ser boas sugestões para indicadores novos ou substitutos. Algumas lacunas podem ter sido identificadas e alguns indicadores podem ser sugeridos para preenchê-las. Se for assim, inclua-os!

É possível que alguns C\&l precisem de alguns ajustes ou modificações. Se for assim, mude-os! 
No final, você pode achar que tem muitos indicadores, ou muitos de um tipo específico. Neste caso, considere aplicar os filtros que você usou durante o desenvolvimento dos C\&l para reduzir o conjunto, ou realizar alguns exercícios de classificação participativa para descobrir quais indicadores são os mais importantes. Observouse que o processo de alteração do conjunto de C\&l é por si só uma boa maneira de compartilhar conhecimento - o processo envolve muita discussão e debate sobre por que as mudanças deveriam ser feitas.

\section{Etapa 7: Seguir adiante/retornar à Etapa 1}

C\&l são usados na forma de espirais contínuas ou ciclo de reflexão, planejamento, ação e observação.

Figura 3. A Espiral do monitoramento (também denominada "Ciclo de aprendizagem").

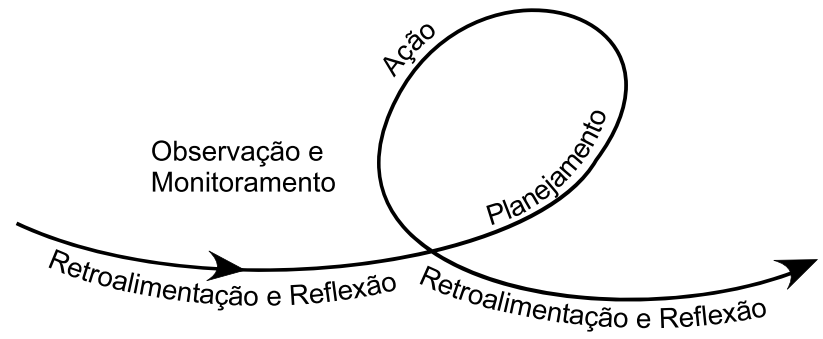

${ }^{28}$ O CIFOR produziu um programa de computador chamado IAMCI (Instrumento de Adaptação e Modificação dos Critérios e Indicadores) para ajudar com as modificações e adaptações do conjunto genérico de C\&l do CIFOR para UMFs. Este programa ainda não foi adaptado a um conjunto de C\&l para MCF ou testado em campo em um processo participativo. Entretanto, se esse for o seu conjunto básico e você tiver acesso a computadores, você pode tentar usá-lo. Veja a seção de referências para informação. 


\section{Conteúdo dos C\&I}

\section{Introduzindo os C\&l selecionados dos três locais de testes do CIFOR $^{29}$}

Esta parte do guia é sobre o conteúdo dos C\&l que foram desenvolvidos nos locais de testes do CIFOR. São apresentados C\&l selecionados de três testes distintos (isto é, uma série de exemplos relacionados e combinados, não um único conjunto de (\&l). Esses exemplos foram criados para ilustrar a amplitude de questões e C\&l relacionados, que foram considerados importantes nos três locais de testes. Eles são apresentados como um ponto de partida para desenvolvimento posterior de C\&l a nível local - um meio de gerar idéias do que pode ser apropriado em um contexto específico. Eles não devem ser vistos como um conjunto definitivo ou genérico de C\&l para MCF. Muitos serão aplicáveis na maioria das áreas de MCF; outros serão mais específicos da sua área mas podem ser adaptados para se adequarem a outros locais. Outros ainda podem não ser relevantes de nenhuma maneira e deveriam ser eliminados e, ainda, alguns que são específicos para outras áreas podem estar ausentes. Adapte!

Deve-se manter em mente que esses c\&l foram desenvolvidos por equipes de cientistas que eram especialistas em disciplinas como Ecologia, Manejo Florestal e Sócioeconomia. Apesar dos conjuntos de C\&l desenvolvidos pelas equipes terem sido modificados após consultas com as comunidades locais nos sítios de testes, e depois de serem avaliadas as condições locais do sítio, eles não são produto da colaboração

\footnotetext{
${ }^{29}$ Uma lista completa de todos os C\&I gerados nos locais de testes do CIFOR pode ser obtida no CIFOR. Veja seção de referências.
} 
participativa total que estamos recomendando neste guia (isto é, o CIFOR aprende fazendo, e a partir das experiências). Como conseqüência, alguns C\&l retiveram uma forte influência científica e são expressos numa linguagem de difícil compreensão para muitos membros das comunidades dependentes da floresta. Linguagem à parte, eles são uma boa indicação das questõeschave que são vistas como vitais para o MCF sustentável e um bom ponto de partida em termos de C\&l.

As equipes de testes encontraram algumas dificuldades, até mesmo confusão, em seu plano original de agrupamento dos C\&l sob os Princípios de Ecologia, Manejo Florestal e Sócioeconomia. Por exemplo, C\&l similares foram agrupados sob Ecologia em um local e sob Manejo florestal em outro local. É possível que isto tenha acontecido devido à estratégia de agrupamento dos C\&l sob Princípios de Ecologia, Manejo florestal e Sócioeconomia refletindo uma visão "científica" de C\&l, de cima para baixo, e uma visão desenvolvida originalmente para o manejo florestal industrial. Essa perspectiva pode não ser capaz de capturar a diversidade, complexidade e inter-relação de fatores que estão relacionados à sustentabilidade ao lidar com MCF. Ela pode, também, não estar refletindo corretamente as percepções de muitas comunidades dependentes da floresta.

Como conseqüência, considerando os objetivos deste guia e a realização de trabalhos futuros com C\&l para MCF, decidimos reagrupar os C\&l sob títulos amplos expressos em quatro princípios básicos ou ideais para MCF sustentável. Esses C\&l deveriam ser coerentes no nível de comunidade. Nós consideramos que eles podem ser um ponto de partida adequado para gerar Princípios definidos e acordados localmente, bem como seus C\&l de apoio. 
Os quatro Princípios ${ }^{30}$ que sintetizamos do trabalho de campo são:

- 0 bem-estar da comunidade (institucional) é garantido

- 0 bem-estar das pessoas é garantido

- A saúde da paisagem florestal é garantida

- 0 meio ambiente externo é favorável ao MFCS

Para cada princípio, há uma breve explicação, seguida por vários grupos de C\&l. Cada grupo de C\&l é indicado pelo seu cabeçalho sublinhado. Cada grupo contém primeiramente uma justificativa muito breve, e em seguida um grupo de exemplos de C\&l retirados dos locais de teste.

Nos exemplos dados, os critérios estão em negrito, os indicadores em itálico e os verificadores em formato normal.

\section{Observe por favor:}

1) 0 propósito desses $C \& I$ não é somente fornecer exemplos de C\&l-chave reais para MCF, mas também ilustrar similaridades e diferenças entre eles, nas diferentes áreas. Assim, lembre-se de que não estamos apresentando um único conjunto de $C \& l$ coerente ou uma única estrutura

${ }^{30}$ Esses princípios emergiram como arcabouços lógicos da pesquisa e dos C\&l desenvolvidos durante os testes de C\&I para MCF do CIFOR. Eles certamente não são a única maneira de organizar Princípios do MCF. Como descrito anteriormente, Princípios deveriam derivar de processos participativos, e serem baseados nas percepções, necessidades e preferências dos usuários

31

Alguns dos C\&l nos exemplos foram desenvolvidos por pessoas que usavam o inglês como segunda língua e outros foram traduzidos posteriormente para o inglês e agora para o português. Com o objetivo de respeitar a intenção e sentido originais dos C\&l, procuramos manter o máximo possível da formulação original, mesmo em casos onde a gramática inglesa não estava tecnicamente correta. Em outros casos, os conjuntos são incompletos, ou não seguem as sugestões para uso recomendadas neste guia. Novamente, o objetivo aqui é somente ilustrar possibilidades, e para isso, os significados e exemplos devem ser bastante claros. 
completa de C\&I- oferecemos Princípios e vários exemplos ou versões de Critérios sobre o mesmo tema, cada qual com seus próprios Indicadores e Verificadores.

2) A numeração dos exemplos de $C \& l$ selecionados se refere aos conjuntos originais de teste de campo dos quais eles foram retirados - ela não se refere a esse conjunto compilado, e por isso pode ser ignorada (a menos que a referência seja feita aos conjuntos completos originais de $C \& l$ gerados nos locais de teste do CIFOR).

\section{Princípio 1. 0 bem-estar da comunidade está garantido}

Ao desenvolver C\&l para o bem-estar da comunidade, a primeira preocupação deve ser com a capacidade que a comunidade tem em organizar e manejar as múltiplas funções, usos e benefícios da floresta coletivamente, de modo que os indivíduos, famílias e outros grupos dividam equitativamente os benefícios e que os recursos florestais continuem a fornecer essas funções, usos e benefícios no futuro.

Muitos estudos recentes sobre sucessos ou fracassos do MCF têm revelado a importância da capacidade da comunidade em se organizar, bem como em desenvolver e cumprir as regras do manejo. Essa importância é devida principalmente à pressão da população, à redução e degradação dos recursos, e à competição externa. A capacidade da comunidade de se organizar, de desenvolver regras de manejo e executá-las, assim como ter a garantia da autoridade e do direito de

\footnotetext{
${ }^{32} \mathrm{O}$ conjunto completo de C\&l gerado nos três locais de teste do CIFOR pode ser obtido no CIFOR. Veja seção de referências.
} 
manejar, foram identificados como fatores vitais para o favorecimento do manejo florestal sustentável.

Em todos os três locais de testes foram desenvolvidos C\&l para tratar dessas questões. Tendo em vista o potencial de uso dos conjuntos como um ponto de partida para futuras situações de MCF, e para comparação entre os locais de teste, agrupamos esses conjuntos de C\&l sob os seguintes títulos.

\section{a. Organizações/instituições comunitárias e participação \\ b. Mecanismos para manejo local (por exemplo, normas, regras, regulamentos etc.) \\ c. Administração de conflitos \\ d. Autoridade para manejar (posse)}

\section{1.a Organizações/instituições comunitárias e participacão}

A fim de manejar a "oferta e demanda" de recursos florestais comunitários - incluindo os direitos e obrigações de distribuição, colaboração e proteção florestal - muitos sistemas de MCF tradicionais desenvolveram formas de organização comunitária. Tais organizações foram estabelecidas com o objetivo de ajudar a comunidade a enfocar o desenvolvimento, a implementação e o cumprimento de regras por meio de incentivos, da persuasão ou da imposição de punições. Portanto, a existência de uma organização comunitária sustentadora e forte, é vista como sendo algo vital para a sustentabilidade do MCF. Em dois dos três locais de testes (Brasil e Indonésia) identificou-se uma ampla participação na tomada de decisão, inclusive com a participação de mulheres, como sendo um pressuposto importante para a sustentabilidade das organizações locais e para a redução de possíveis conflitos. 
Brasil

6.4 A comunidade participa e monitora todos os processos de planejamento de qualquer sistema de manejo a ser executado dentro da área agroflorestal em que ela causa impacto.

6.4.1 Participação ativa da comunidade na concepção e monitoramento dos sistemas de manejo dos recursos agroflorestais.

6.4.1.a (A percepção que) A liderança (s) na comunidade é representativa de todos os grupos e facções existentes na comunidade.

6.4.1.b A maioria da população adulta da comunidade conhece e concorda com o sistema de manejo.

6.6.1 A comunidade possui formas de organização interna e entre outras comunidades.

6.6.1.a Reconhecimento da existência de organizações ("de fato" e legalmente).

6.6.1.c Relatos individuais ou coletivos da participação de membros da comunidade em associações, sindicatos e organizações políticas.

6.6.2 Participação ativa de mulheres em discussões e decisões referentes ao bem-estar da comunidade.

6.6.2.a Existência de formas de associação que contemplam questões referentes ao gênero.

6.6.2.b Representação de mulheres em associações dentro da comunidade e entre comunidades.

República dos Camarões

7.1 Existem instituições ou organizações para atender aos diversos interesses de diferentes usuários da floresta e grupos de interesse. 
7.1.1.1 Conselho de curandeiros ou anciões.

7.1.3.1 Associações e grupos representativos de desenvolvimento comunitário.

7.1.3.2 Respeito/reconhecimento das decisões do grupo/associação de desenvolvimento.

Indonésia

5.3 A organização social local tem a capacidade de fazer cumprir a lei costumeira e outros regulamentos.

5.3.1 São organizadas reuniões sobre problemas ambientais e de uso da terra.

5.3.2 As mulheres têm representatividade igualitária nas reuniões e tomadas de decisão.

5.3.2.1 As mulheres estão presentes nas reuniões.

5.3.2.2 As mulheres são envolvidas nas discussões.

5.3.3 Existem tomadas de decisões de maneira participativa.

5.3.3.1 As decisões são tomadas nas reuniões de membros adultos da comunidade.

5.3.3.2 Os participantes compreendem o assunto das discussões.

5.3.3.3 As autoridades não monopolizam a discussão.

5.3.3.4 As pessoas concordam sobre a discussão dentro e fora da reunião.

\section{1.b Mecanismos para manejo local (por exemplo, normas, regras, regulamentos etc.)}

A fim de implementar as decisões da comunidade sobre o manejo, muitos sistemas duradouros de MCF desenvolveram uma série de instrumentos de manejo para regular e controlar o uso dos recursos florestais pelos membros da comunidade. 0 termo mecanismos para manejo é usado aqui para abranger todos os instrumentos formais e informais, incluindo as regras, normas, 
costumes, tabus, regulamentos etc, desenvolvidos pela comunidade. Esses mecanismos freqüentemente são complexos e sutis e, como as próprias organizações, estão fundamentados nos meios cultural, espiritual e ecológico locais. Mecanismos tais como punições para lidar com pessoas que desobedecem as regras foram identificados como sendo importantes no local de teste da Indonésia (isto é, através do sistema tradicional adat ${ }^{\mathrm{NT}}$ ). Tanto na Indonésia como na República dos Camarões, observou-se que a capacidade da comunidade de desenvolver suas regras como uma forma de se adaptar às mudanças circunstanciais tem sido crucial à sustentabilidade das instituições comunitárias.

\section{Brasil}

\subsection{A comunidade tem desenvolvido mecanismos para monitoramento e controle das atividades produtivas.}

5.6.1 Existência de mecanismos na comunidade para patrulhar e controlar os vários estágios da extração de madeira realizada tanto pela comunidade como por pessoas de fora da comunidade.

5.6.2 Existência de mecanismos na comunidade para patrulhar e controlar a extração de Produtos Florestais Não-Madeireiros (PFNMs) pelos membros da comunidade e/ou pessoas de fora da comunidade.

5.6.3 Monitoramento e controle da pesca realizada por membros da comunidade e/ou de fora da comunidade.

5.6.4 A comunidade possui mecanismos para controlar a coleta e a venda de animais e plantas ornamentais.

6.2.1.c Regras da comunidade sobre direitos de uso, posse e propriedade sobre os recursos agroflorestais.

${ }^{\mathrm{NT}}$ Lei Costumeira local 
República dos Camarões

5.4 0 acesso ao bens florestais comuns da comunidade é regulado através de ação e apoio coletivos.

5.4.2 Desenvolvimento de novas regras e práticas de exploração em resposta às mudanças evidenciadas na base dos recursos.

6.3 Existem sistemas locais para monitoramento e avaliação de diferentes recursos florestais.

6.3.2 Os membros da comunidade contribuem efetivamente para a avaliação do recurso florestal.

7.2 As instituições comunitárias têm a capacidade de determinar e distribuir benefícios dos recursos florestais.

7.2.1 A comunidade possui normas e valores para a distribuição de carne de caça de animais relativamente grandes.

7.2.2 Os tabus alimentares da comunidade funcionam.

Indonésia

5.1 A lei costumeira e outros regulamentos asseguram os sistemas de uso sustentável da terra.

5.1.1 Há punições para aqueles que desobedecem as regras.

5.1.1.1 Punições específicas vinculadas a sistemas específicos de uso da terra.

5.1.2.3 Casos recentes de aplicação de punições.

5.1.2 Todos os segmentos da comunidade respeitam as leis tradicionais e outros regulamentos relacionados ao sistema de uso sustentável da terra.

5.1.4 As regras que asseguram o uso sustentável da floresta são respeitadas.

5.1.5 As regras que asseguram a sustentabilidade das funções de serviço da floresta são respeitadas. 
5.1.6 As regras que asseguram a sustentabilidade do tembawang (hortos florestais) são respeitadas.

5.1.7 As regras relacionadas às práticas de agricultura de corte e queima/ladang que asseguram um período apropriado de pousio são respeitadas.

5.3.4 Novos regulamentos e punições que tratam dos novos problemas de desenvolvimento relacionados ao uso da terra e aos recursos naturais ainda estão sendo desenvolvidos.

\section{1.c Administração de conflitos}

Em todos os três locais reconheceu-se a necessidade da comunidade possuir mecanismos para lidar com conflitos quando eles surgem. Esses mecanismos podem ser formais ou informais. Para que se tornem efetivos, é também necessário que haja consenso ou respeito por eles. Além disso, pode ser importante as comunidades possuírem capacidade de usar mecanismos externos, formais ou legais para resolver conflitos (ver 4.b).

\section{Brasil}

\subsection{Devem existir medidas e instituições para resolução de conflitos.}

6.2.1 Existem mecanismos informais para resolução e negociação dos conflitos na comunidade, disputas e queixas familiares relacionadas ao uso, posse e propriedade de recursos agroflorestais.

6.2.1.b Documentação de negociações e resolução de conflitos relacionados aos recursos agroflorestais. 


\section{República dos Camarões}

5.1.2 Decisões referentes à resolução de conflitos são tomadas por instituições na comunidade.

5.1.2.2 Número de casos de conflitos sobre reivindicação de terra registrados e resolvidos na comunidade, comparado com o número desses casos resolvidos pela Lei estadual.

7.1.1 As decisões das instituições de resolução de conflitos são respeitadas.

\section{Indonésia}

5.1.3 Existe um mecanismo para resolução de conflitos.

5.1.3.1 Os membros adultos da comunidade podem explicar como são resolvidos os conflitos relacionados ao uso da terra.

5.1.3.2 Há um consenso sobre como é resolvido o conflito relacionado ao uso da terra.

5.1.3.3 Casos recentes de resolução tradicional de conflitos relacionados ao uso da terra.

\section{1.d Autoridade para manejar (posse)}

A comunidade requer a segurança da posse sobre seus recursos a fim de ter autoridade para manejá-los. Da mesma maneira, sem a segurança da posse, as pessoas freqüentemente hesitam em investir em esforços de manejo a longo prazo. Todos os três locais incluem Critérios ou Indicadores referentes ao reconhecimento formal ou legal (de direito) do sistema de posse da comunidade. As questões relacionadas à posse também podem incluir referência aos limites da terra comum ou das florestas da comunidade, à existência de mapas mostrando essas fronteiras, e/ou ao reconhecimento dos 
freqüentemente complexos sistemas de direitos e usos tradicionais que se desenvolveram na comunidade (ver também 2.d e 4.b).

Brasil

6.1 Os direitos de ocupação, posse e usufruto da terra pela população local são garantidos a longo prazo.

6.1.1 Os direitos costumeiros de posse da terra e os acordos de concessão relativos ao manejo de agroflorestal são reconhecidos.

6.1.1.a Levantamento dos direitos de uso da terra e direitos de posse e propriedade.

6.1.1.b Levantamento dos direitos legais e tradicionais de concessão de uso da terra e dos direitos de posse e propriedade.

6.1.1.c Existência de acordos costumeiros relativos ao uso da terra e aos recursos agroflorestais, dentro da comunidade.

República dos Camarões

5.1 Os direitos de acesso de longo prazo da comunidade à terra e aos recursos florestais são claramente definidos, conhecidos e respeitados.

5.1.1 Os procedimentos de apropriação da terra são aceitos e respeitados.

5.1.3 Os sistemas legais formais favorecem o sistema costumeiro de posse.

5.1.4 Os limites da área da comunidade são conhecidos e respeitados pelos membros da comunidade. 
Indonésia

4.1 A segurança do sistema de posse da comunidade é garantida pelo estado.

4.1.1 A segurança do sistema de posse da comunidade é garantida nas leis do estado e regulamentos.

4.1.2 Os direitos de propriedade da comunidade são indicados nos mapas oficiais de uso da terra.

4.1.3 Tradução e adaptação da TGHK (Tata Guna Hutan Kesepakatan) para TGLDK (Tata Guna Lahan Desa Kesepakatan).

\section{Princípio 2. 0 bem-estar das pessoas está garantido}

É amplamente reconhecido que as pessoas que sobrevivem de áreas florestadas, em dependência dos recursos florestais, e cujo bem-estar é aumentado por sua interação com a floresta, têm um interesse garantido na sustentabilidade da floresta. Este Princípio está baseado no mesmo ideal. Uma grande variedade de Critérios e Indicadores de todos os três locais expressam os múltiplos valores da floresta para a população local. Subdividimos nossos exemplos de c\&l em quatro grandes áreas, baseados na noção recorrente que emergiu dos conjuntos de que as pessoas necessitam ser "saudáveis, prósperas e sábias" para capturar a questão vital da segurança de acesso aos recursos entre gerações. As quatro sub-divisões são:

a. Saúde e alimentação

b. Prosperidade (modos de vida, distribuição de custos e benefícios, eqüidade)

c. Sabedoria, ética de sustentabilidade e troca de conhecimento

d. Acordos sobre a posse na comunidade 


\section{2.a Saúde e alimentação}

Tanto no Brasil como na República dos Camarões, foram desenvolvidos Critérios e Indicadores para expressar a idéia de que a interação com a floresta fornece benefícios diretos para a saúde e o bemestar físico das pessoas. Muitos desses C\&l mencionam a importância dos produtos florestais na alimentação. Na Indonésia, não foi feita nenhuma referência à alimentação ou saúde das pessoas locais. Isso não é comum. Na maioria dos C\&l para manejo florestal sustentável, a saúde das pessoas locais é considerada um Critério importante. No Brasil, incluiuse uma idéia adicional de que o controle do crescimento populacional e da natalidade são importantes para a sustentabilidade.

\section{Brasil}

6.7 As atividades de manejo aplicadas aos recursos agroflorestais têm contribuído significativamente para 0 bem-estar biológico, sócio-econômico e cultural da população local.

6.7.5.b Consumo de alimentos pela família com atenção especial aos produtos agroflorestais.

6.7.5.f Crescimento populacional estável ou lento.

6.7.5.g Uso e acesso das mulheres ao planejamento familiar e métodos contraceptivos.

6.7.8.c Repertório da culinária tradicional associado ao uso de uma ampla variedade de produtos agroflorestais.

3.1.1 A importância sócio-econômica das fontes aquáticas de proteína animal para a comunidade local permanece significativa.

2.1.3 A carne de caça ainda é importante na alimentação local. 
República dos Camarões

1.60 bem-estar da população é garantido.

1.6.1 A saúde é garantida por produtos medicinais coletados da floresta.

1.6.1.1 Evidência de coleta de cascas, sementes, frutos e folhagem e consumo local adequado.

1.6.2 Muitos produtos consumidos pela população local são retirados do ecossistema florestal.

1.6.2.1 Hábitos alimentares dependem do ecossistema florestal local.

1.6.2.2 Evidência do uso de diversas receitas.

\subsection{A função da floresta natural na saúde da comunidade está} sendo conscientemente preservada.

3.2.1 Há uma variedade de produtos florestais de valor nutricional que suplementam os pratos e refeições locais.

3.2.1.2 Contribuições à alimentação local pelos alimentos retirados da floresta.

3.2.2 Há um compêndio de árvores medicinais, arbustos, ervas, cobras, sapos etc., usados pelos habitantes locais para tratar doenças e enfermidades físicas.

3.2.3 Bacias hidrográficas e canais são protegidos visando a saúde da comunidade.

3.2.4 O uso do fogo para limpeza da terra é reduzido para evitar as doenças respiratórias.

\section{2.b Prosperidade (modos de vida, distribuição de custos e benefícios, eqüidade)}

Em todos os três locais houve muitos exemplos de critérios e indicadores que se referiam às pessoas locais como sendo dependentes da floresta para sua sobrevivência. As questões aqui incluem benefícios econômicos obtidos tanto diretamente da floresta 
como através de indústrias caseiras. Estas agregam valor à matéria-prima da floresta através do artesanato e/ou da geração de emprego. Os C\&l da República dos Camarões e do Brasil enfatizaram o tema dos múltiplos e diversos produtos florestais, e a importância de diferentes grupos com interesse na floresta se complementarem pelo uso de recursos diferentes. A Indonésia enfatizou a distribuição eqüitativa dos produtos florestais (ver também 4.c).

\section{Brasil}

5.7 Os benefícios derivados das atividades produtivas têm servido como um incentivo para perpetuar essas atividades de uma maneira sustentável.

5.7.1 Existência de esforços contínuos para diversificar e aumentar a capacidade do processo de agregação de valor com o objetivo de aumentar o valor agregado bruto dos produtos.

6.7.1 As atividades de manejo aplicadas aos recursos agroflorestais produzem subsídios econômicos para a manutenção de empreendimentos de pequena escala e de indústrias caseiras.

6.7.2 O nível de dependência da matéria-prima produzida e obtida na comunidade.

6.7.4 As atividades de manejo dos recursos agroflorestais contribuem economicamente para o acesso da comunidade à educação, saúde e outros serviços sociais.

6.7.5 Existência de benefícios efetivos para a subsistência e reprodução das unidades domésticas derivados do manejo de recursos agroflorestais.

6.7.5.a Quantificação da produção agroflorestal na unidade doméstica.

6.7.5.c Inventário dos bens e utensílios domésticos da família. 
6.7.5.d Flutuações do rendimento da unidade familiar proveniente das atividades de manejo dos recursos agroflorestais.

República dos Camarões

5.2 Os produtos florestais contribuem significativamente para o bem-estar sócio-econômico das diferentes faixas etárias e sexos da comunidade.

5.2.1 Importância dos produtos florestais nos rendimentos domésticos monetários e não-monetários.

3.3 Os diferentes grupos de interesse em produtos florestais e usuários da floresta convivem harmoniosamente.

3.3.1 O interesse dos vários grupos comunitários de usuários da floresta se complementam e não competem adversamente.

3.3.2 Os benefícios florestais suprem diversos setores da comunidade rural.

3.3.2.1 Existência de indústrias caseiras que usam habilidades tradicionais e encorajam a colheita e uso racionais de matérias-primas retiradas da floresta.

3.3.2.2 Emprego oferecido aos comunitários pelas indústrias caseiras.

3.3.2.3 Existência de produtos de valor agregado produzidos localmente para uso e venda locais.

3.3.2.5 A seleção de plantas, espécies e de padrões de artesanato resulta em produtos de valor agregado com longo tempo de vida útil (por exemplo, pilões, canoas etc.). 


\section{Indonésia}

\subsection{As leis costumeiras e outros regulamentos asseguram} acesso justo aos recursos naturais da comunidade $e$ distribuição justa de seus produtos entre os membros da comunidade.

5.2.1 As regras asseguram o acesso justo de todos os atores à floresta.

5.2.2 As regras asseguram a distribuição justa dos produtos do horto florestal a todos os atores.

5.2.3 As regras asseguram a distribuição justa de água para irrigação onde existem campos de arroz.

3.4 0 horto florestal é capaz de manter a sobrevivência das pessoas.

3.4.1 O horto florestal produz frutas para comercialização e outros ítens de subsistência.

\section{2.c Sabedoria, ética de sustentabilidade e troca de conhecimento}

Um aspecto importante do manejo florestal sustentável é que a base de conhecimento da comunidade esteja ativa e bem, e que o manejo seja baseado na sabedoria coletiva da comunidade. Portanto, a transferência de conhecimento entre gerações dos idosos para os jovens é vital para manter esta base de conhecimento no futuro, como foi enfatizado em todos os três locais de testes. No conjunto de C\&l da Indonésia por exemplo, a transferência de conhecimento através da educação foi expressa como um Princípio. Os conjuntos de C\&l do Brasil e Indonésia também se referem ao componente "moral" do conhecimento tradicional (consciência local, ética ambiental), o qual fundamenta as práticas tradicionais. 0 conhecimento tradicional parece ser importante para a identidade cultural e espiritual de muitas populações nativas por estar firmemente arraigado à floresta. 
Os conjuntos de C\&l mostram que a importância do conhecimento tradicional para o manejo florestal sustentável é tão grande que não pode ser suficientemente enfatizada. 0 conhecimento não só aparece com freqüência, mas, como no caso do conjunto de C\&l da República dos Camarões, por exemplo, também aparece no alto na hierarquia de C\&l (por exemplo, o uso do conhecimento tradicional é um Princípio de sustentabilidade). Embora tenhamos especificamente incluído o conhecimento dentro do Princípio sobre bem-estar das pessoas, essa é uma questão presente em todas as áreas, e provavelmente a expressão "conhecimento sobre" será comum em todo conjunto efetivo de Critérios e Indicadores (ver também 4.d).

\section{Brasil}

\subsection{A consciência e conhecimento locais sobre o uso e manejo dos recursos agroflorestais demonstram uma ética de conservação e uso sustentável da terra.}

6.8.1 Amplo conhecimento local sobre o uso de recursos agroflorestais, especialmente de PFNMs.

6.8.2 Uso de PFNMs em tecnologias e infraestruturas locais.

6.8.2.a Classificação tradicional de produtos agroflorestais usados na fabricação e produção de artefatos.

6.8.3 Evidência de códigos simbólicos e mitos que têm um efeito regulador, os quais contribuem para a consenvação dos recursos agroflorestais.

6.8.3.a Efeito regulador evidente das narrativas de mitos.

6.7.7 Transmissão e perpetuação (escrita e oral) do conhecimento tradicional e mitologia.

6.7.8 A identidade cultural está intimamente associada com a paisagem agroflorestal, com seus vários usos e sua ritualização. 


\section{República dos Camarões}

6.1 A estrutura social permite a transmissão dos sistemas de conhecimento existentes.

6.1.1 Os contos e provérbios populares demonstram as relações floresta/pessoas.

6.1.2 Diferentes grupos de usuários realizam expedições coletivas de exploração da floresta.

6.1.3 As expedições de exploração da floresta incluem a transmissão de conhecimento.

6.2 O conhecimento sobre a floresta é usado como um mecanismo para garantir sobrevivência mínima aos membros da comunidade.

6.2.1 A freqüência de visitas à floresta indica dependência.

Indonésia

3.1.3 Existe um conceito tradicional de conservação.

7.1.3 A educação não-formal está funcionando.

7.1.3.1 O relato de estórias ainda é feito pelos anciãos para os mais jovens.

7.1.3.2 A história local ainda é transmitida para a geração mais jovem.

7.1.3.3 o conhecimento local sobre manejo dos recursos naturais ainda é transmitido para a geração mais jovem. 


\section{2.d Acordos sobre a posse na comunidade}

Em muitos MCF duradouros, a necessidade de assegurar o acesso eqüitativo à floresta e aos outros recursos tem levado à evolução de acordos locais sobre a posse. Esses acordos são geralmente feitos entre o indivíduo (e/ou família ou grupo) e a comunidade; os acordos são (pelo menos inicialmente) aceitáveis para a cultura local e para as necessidades do manejo dos recursos, e usualmente baseados em regras e normas acordadas. Esses acordos definem, em termos espacial e temporal, a relação entre um indivíduo (família/grupo), a comunidade e a área do recurso, i.e., "Quem pode fazer o que, e onde". Relações de posse bem definidas e aceitáveis são vitais para que as pessoas sintam-se incentivadas a investir, proteger e a garantir o compromisso entre gerações. Direitos de uso justos são importantes para o bem-estar das pessoas, como foi enfatizado no Brasil. A herança e os meios de transmitir os direitos às futuras gerações são aspectos importantes da sustentabilidade. Esta seção sobre posse individual têm ligações fortes com outras seções, incluindo a da posse comunitária ou autoridade para manejar (ver 1.d), e a questão da distribuição na seção sobre prosperidade (ver 2.b). No Brasil e República dos Camarões, a posse individual dos recursos foi um Critério. Entretanto, na Indonésia, a questão da posse individual foi tratada como transversal e, dessa forma, aparece como Verificador em vários lugares. 
Brasil

6.3 0 acesso e o uso de terras comuns e recursos agroflorestais são garantidos a todos os membros da comunidade independente de sexo, cor, religião ou classe social.

6.3.1 Existem normas para regular o acesso aos recursos agroflorestais.

6.2.1.c Identificação de regras internas comunitárias sobre os direitos de uso, posse e propriedade sobre os recursos agroflorestais.

República dos Camarões

5.1 Evidências de acesso/direitos de uso são demonstradas pelos membros da comunidade.

5.1.1 Procedimentos de apropriação de terras são aceitos e respeitados.

5.1.1.1 História de uso e/ou ocupação de terras.

5.1.1.2 Padrões de herança de propriedade.

Indonésia

5.2.2.2 Direitos de propriedade comum e privada garantidos sobre o horto florestal.

5.2.2.3 Regras claras sobre herança.

5.2.2.4 Regras claras sobre os direitos de extração de produtos do horto florestal.

6.1.2.4 Regras sobre a posse de PFNMs. 


\section{Princípio 3. A saúde da floresta está garantida}

Este Princípio expressa a idéia de que toda a paisagem está em boas condições como um resultado de seu manejo. Este é um Princípio amplamente reconhecido cujo objetivo é ser geral o bastante para capturar as muitas e diferentes maneiras nas quais diferentes comunidades pensarão sobre seus recursos. 0 Princípio inclui: a situação da terra e dos cursos d'água; a saúde da ecologia da floresta; a condição e o manejo de áreas da paisagem usadas permanente ou temporariamente para cultivos. Também inclui "melhores práticas" para uma extensa variedade de possíveis intervenções humanas na floresta, incluindo a coleta de PFNMs (plantas e animais), extração de madeira, rotação de corte e queima, agrossilvicultura e silvicultura.

Em muitos conjuntos convencionais de $C \& l$, as questões discutidas aqui são geralmente divididas em pelo menos dois conjuntos - ecologia e manejo florestal. Todavia, em todos os três locais de teste observou-se que essas subdivisões eram impossíveis. A caça é um assunto de biodiversidade ou é parte do manejo florestal? Em muitos contextos de manejo comunitário e tradicional, não há distinção entre floresta "manejada" e ecossistema "natural". A comunidade maneja a ecologia da paisagem como um todo. Dessa maneira, este Princípio amplo tenta abranger a integridade da paisagem florestal de uma maneira mais holística. Duas comunidades não definirão o manejo de suas florestas em Critérios da mesma maneira. Houve diferenças significativas na estrutura dos C\&l entre os três locais de teste. Apresentamos exemplos de C\&l para este Princípio sob as seguintes sub-divisões:
a. Planejamento (zoneamento e áreas protegidas)
b. Manejo das funções do ecossistema (terra, água e fogo)
c. Intervenções produtivas 1 (agricultura e agrofloresteria)
d. Intervenções produtivas 2 (PFNMs vegetais)
e. Intervenções produtivas 3 (PFNMs animais) 


\section{f. Intervenções produtivas 4 (madeira) \\ g. Saúde da floresta 1 (biodiversidade) \\ h. Saúde da floresta 2 (estrutura e regeneração) \\ i. Diversidade da paisagem (fragmentação e mosaicos)}

\section{3.a. Planejamento (zoneamento e áreas protegidas)}

Esta seção inclui C\&l que reconhecem que a paisagem florestal não é homogênea e que seu manejo deve considerar os diferentes tipos de terra ou zonas. Ela inclui áreas protegidas e lugares sagrados. Esta seção relaciona-se com a questão da diversidade da paisagem (ver 3.i) e com questões de limite e posse (ver 1.d e 2.d).

\section{Brasil}

4.1 A manutenção de longo prazo de áreas de reserva e indivíduos reprodutivos é considerada pela comunidade a fim de garantir a sobrevivência das populações exploradas.

\subsubsection{Reservas florestais e santuários com tamanho e distribuição adequados dentro da área de MCF são mantidos.}

5.1.2 Existência de zonas (áreas definidas para diferentes intensidades de uso de acordo com o potencial do recurso).

2.1.5 Existência de áreas onde dificilmente ou nunca há caçadas dentro da área de acesso aos caçadores pertencentes à comunidade.

5.2.1 Existência de plano de manejo e plano anual para madeira.

5.3.1 Existência de planos de manejo e planos anuais para PFNMs.

6.7.6 O respeito e a proteção de sítios com significado cultural especial são priorizados na alocação de todas as formas de uso e exploração de recursos naturais. 
República dos Camarões

5.3 Os sítios de especial valor sócio-cultural, histórico e turístico para as comunidades locais são conhecidos e protegidos por mecanismos de controle social.

5.3.1 Existem sítios místicos de significado sócio-cultural para as comunidades.

3.1 Os membros da vila possuem conhecimento suficiente sobre a composição e distribuição dos diferentes tipos de floresta.

3.1.1 Os limites da floresta e todos os limites com as vilas adjacentes são conhecidos e respeitados por todos os interessados.

3.1.1.2 Tipos diferentes de floresta, tais como pântanos; espécies indicadoras de florestas secundárias; áreas de florestas ricas em espécies; espécies madeireiras de valor; arbustos; ervas; cursos d'água; espécies de peixe, e suas localizações nas florestas, são conhecidos com alto grau de precisão.

Indonésia

2.2 O manejo de cada sistema de uso da terra leva em consideração a caracterização e delimitação da área de preservação e áreas de diferentes intensidades de uso.

2.2.1 As áreas de presenvação são de propriedade coletiva e aplica-se baixa intensidade de uso.

2.2.2 Terras agrícolas permanentes são de propriedade individual e aplica-se alta intensidade de uso.

1.1.1 As áreas de importância ecológica são reconhecidas e protegidas. 


\section{3.b Manejo das funções do ecossistema (terra, água e fogo)}

Esta seção reconhece que manejar a paisagem florestal envolve muito mais coisas do que manejar árvores. Refletindo o fato de que muitas pessoas que vivem na floresta são ribeirinhos que dependem dos cursos d'água para transporte, alimento, irrigação e saúde, o manejo dos recursos hídricos mostrou-se uma questão importante em todos os três locais de teste. 0 manejo do fogo também é importante em todos os locais. 0 manejo do solo é significativo nos conjuntos da República dos Camarões e da Indonésia. Todas as três questões estão interelacionadas. 0 manejo dos recursos hídricos afeta o solo através da erosão e o manejo do fogo afeta o solo através da contribuição das cinzas para a fertilidade. 0 manejo eficaz desses recursos essenciais aumenta a sustentabilidade. A abordagem para avaliação destes manejos diferem grandemente nos três locais de teste: no Brasil optou-se por avaliar a condição do recurso (ver os Verificadores para qualidade da água), e nos outros dois locais deu-se preferência à avaliação das práticas de manejo (ver Verificadores para manejo do fogo da Indonésia).

\section{Brasil}

1.40 risco de incêndios acidentais em áreas de pousio e floresta primária é minimizado pelo uso de técnicas apropriadas de manejo do fogo.

1.4.1 Nenhuma ocorrência de incêndios florestais acidentais.

5.5.4 A comunidade possui regras e regulamentos para o uso controlado do fogo na preparação de áreas para agricultura, na limpeza de pastos e em outras atividades.

1.5 Manutenção da integridade ecológica de todos os ecossistemas aquáticos (rios, igarapés, lagos etc.).

1.5.1 Manutenção de regimes de inundação e da produtividade de canais fluviais e outros processos naturais que 
sustentam ou subsidiam os animais e plantas aquáticas (integridade física).

1.5.2 Ausência de processos de contaminação aquática (qualidade satisfatória da água de um ponto de vista químico e biológico).

1.5.2.1 Transparência, odor e sabor da água.

1.5.2.2 Ocorrência de florescimento de algas e mortalidade anormal de peixes.

1.5.2.3 Ocorrência de contaminação por coliformes fecais.

\section{República dos Camarões}

1.7 Os recursos hídricos são manejados de maneira apropriada.

1.7.1 Há uma estação para pesca bem respeitada.

1.7.2 O acesso aos cursos d'água para pesca é regulado e controlado.

1.7.3 Os instrumentos e métodos de pesca asseguram a reprodução de peixes.

1.7.4 São criados açudes de desova para reduzir a pressão sobre os peixes.

1.4.2 As práticas agrícolas têm efeitos benéficos no curto prazo sobre a terra cultivável, o solo e as árvores.

1.4.2.1 Presenação de árvores fertilizadoras durante a limpeza da terra.

1.4.2.2 Manutenção de alguma cobertura do solo após a limpeza da terra.

1.4.2.5 Quebra da dormência de sementes arbóreas pela ação do fogo.

4.2.1.2 Atenção a fatores climáticos e sazonais na época de incêndios agrícolas.

1.4.2.6 Disponibilização de nutrientes minerais pelas cinzas.

1.4.4.5 Produção e uso de composto.

1.4.3 Os pousios são suficientemente longos para permitir a recomposição do solo. 


\section{Indonésia}

\subsection{As funções críticas do ecossistema são preservadas.}

1.1.2 As fontes d'água são protegidas.

1.1.3 A qualidade da água e do solo é mantida para garantir a sustentabilidade do ecossistema.

\subsubsection{A erosão do solo é minimizada.}

\subsection{Cada sistema de uso da terra está situado em solos adequados.}

2.1.1 Há conhecimento local suficiente sobre os tipos de solo e fertilidade/vegetação de pousio.

3.7.3 O manejo do fogo é aplicado para abrir roçado.

3.7.3.1 Evidência de quebra-fogo (aceiros) antes da queimada.

3.7.3.2 A queimada considera a direção do vento e sua velocidade.

3.7.3.3 Evidência de queimada da parte mais baixa para a parte mais alta.

3.7.3.5 Ausência de plantas danificadas causadas pelo fogo descontrolado.

\section{3.c Intervenções produtivas 1 (agricultura e agrofloresteria)}

Os membros da comunidade consideram que a análise do manejo sustentável de florestas deve levar em conta a agrofloresteria e áreas cultivadas na paisagem (ver Quadro 3). 0 bom manejo dessas áreas com ações para intensificação e otimização são consideradas maneiras importantes de reduzir o impacto sobre os recursos florestais. Nos três locais foi identificada uma ampla variedade de boas práticas para sustentabilidade, incluindo: técnicas de baixo impacto, métodos para aumentar a produção sem expandir a área de cultivo, otimização, desenvolvimento de agricultura permanente onde apropriado, uso correto do cronograma para práticas sazonais, e boa criação de animais domésticos. 
Quadro 3. Exemplos de intervenções produtivas nos três locais de teste do CIFOR.

\section{Vilas de São Pedro e Cachoeira do Maró, Pará, Brasil}

Essas comunidades praticam a agricultura migratória. A mandioca é a cultura mais importante. Ela é transformada em farinha e a pequena produção excedente é transportada por barcos até os mercados. Muitas famílias residentes possuem pequenas plantações de seringueira. A floresta da comunidade inclui algumas áreas com árvores bastante espalhadas de Castanha-do-Brasil. Essa floresta também é relativamente rica em outras espécies de PFNMs úteis. Pequenas empresas de construção de barcos usam madeira, fibras e resinas da floresta. Estes habilidosos construtores de barcos estão preocupados em treinar aprendizes. Para a derrubada de árvores e sua conversão em pranchas, ainda se utilizam principalmente de machados. A caça e pesca são atividades importantes, havendo muitos membros da comunidade especializados em uma ou outra.

Vilas Eyek II e Akak/Bitetele, Província Central, República dos Camarões. Essas vilas Bantus Bulu estão localizadas em uma zona rica em floresta já super explorada. São comunidades que, recentemente, desafiaram com sucesso empresas de exploração que fizeram duas tentativas para entrar na área. As comunidades surgiram nos anos vinte, quando ancestrais de seus habitantes atuais chegaram na área após décadas de migração lenta pelo país. A pouca infraestrutura os mantém relativamente isolados da economia de mercado, e reforça seu grau de dependência comparativamente alto da floresta para a subsistência. Agricultores migratórios, muitas famílias também têm pequenas parcelas com plantação de café e/ou cacau. Desde a metade dos anos oitenta essas culturas perenes comerciais têm sido menosprezadas devido aos preços em queda, o que resultou na redução das taxas de conversão de florestas e de capoeiras. Os membros da vila caçam e pescam regularmente e coletam PFNMs da floresta, tais como alimentos, folhas para embalagem, remédios, fibras, materiais de construção e materiais para a produção de artesanato. Os PFNMs mais importantes localmente incluem o junco e a ráfia, folhas para embalagem e vários frutos e especiarias incluindo "bush mango" (Irvingia gabonensis), frutos moabi (Baillonella toxisperma) e sementes de Ricinodendron heudelotii. Sob a autoridade dos chefes da vila, líderes e pessoas de destaque, essas vilas têm desenvolvido regras/leis e regulamentos para arbitrar sobre o fluxo de benefícios derivados da floresta.

\section{Bedigong e Darok, Distrito de Sanggau, Kalimantan Ocidental, Indonésia.}

Os membros dessas vilas também praticam a agricultura migratória. Sua principal produção econômica é a seringueira, cultivada em pequenos povoamentos. As vilas estão entre as mais famosas por seus hortos florestais (Tembawang). Esses hortos são plantados em áreas agrícolas quando são abandonadas. São geralmente muito mais ricos em espécies florestais úteis do que a floresta natural. A espécie dominante é a tengkawang (Shorea macrophyla), uma ánore alta da floresta que produz castanhas, das quais se extrai um óleo muito valorizado comercialmente, sendo a segunda em importância econômica após a seringueira. Outros produtos florestais localmente importantes são o mel, o junco, cavacos e madeira dura. Em Darok, a maior vila, alguns hortos foram convertidos em áreas de plantio de arroz irrigado. 
Brasil

5.5 As práticas agrícolas são executadas de uma maneira que minimizam seu impacto na floresta.

5.5.5 A aplicação de tratos culturais de impacto reduzido (controle de pragas e doenças, podas etc.).

República dos Camarões

1.4 Os efeitos negativos da agricultura sobre o ecossistema florestal são minimizados.

1.4.1 As atividades agrícolas são localizadas.

1.4.4 Tomam-se medidas para aumentar a produção agrícola.

2.1.1.4 Culturas mistas e cultivos sequenciais ajudam a garantir alimento durante todo $\mathrm{o}$ ano, e fazem provisões para a entresafra.

4.2.1 As terras agrícolas são limpas (cortadas e queimadas) logo antes da estação chuvosa para que as culturas sejam plantadas na época certa.

4.2.1.1 Nenhum sinal de cronograma errado ou atrasos na preparação da terra tais como desperdício de terra preparada e perda de produção.

Indonésia

3.7 Agricultura sustentável de baixo uso de insumos é aplicada.

3.7.1 O cultivo de seringueiras é intensificado.

3.7.2 Existe distribuição de classe de idade.

\subsection{Otimização do sistema agrossilvicultural local.}

6.2.1 Otimização do horto florestal.

6.2.3 A produtividade e a qualidade dos seringais deve ser aumentada. 
6.2.3.1 Evidência de tecnologia apropriada para o melhoramento de árvores.

6.2.3.2 Evidência de tecnologia apropriada para póscolheita e processamento.

6.2.4 Há política e atividade para racionalizar o sistema de corte e queima.

6.3 A agricultura permanente é desenvolvida onde as condições sócio-econômicas permitem.

6.3.1 Há acordo entre os atores sobre a conversão de parte do ambiente em agricultura de irrigação.

6.3.3 Há uma criação de animais domésticos apropriada.

\section{3.d Intervenções produtivas 2 (PFNMs vegetais)}

Os Produtos Florestais Não-Madeireiros (PFNMs) desempenham um papel importante no dia-a-dia das comunidades que dependem da floresta. Além disso, uma grande riqueza de conhecimentos que envolve melhores práticas em seu manejo e colheita. Todavia, é evidente que seria impraticável desenvolver C\&I para cada intervenção específica. Nos três locais de teste, alguns Critérios gerais para extração sustentável foram desenvolvidos com alguns Indicadores específicos para PFNMs importantes. Indicadores para PFNMs provavelmente são altamente específicos para os produtos florestais da área local. Todas as questões relativas a PFNM também referem-se aos C\&l de biodiversidade (ver 3.g). 
Brasil

5.3 A exploração de produtos florestais não-madeireiros é baseada em práticas sustentáveis.

5.3.2 Adotam-se técnicas de baixo impacto.

5.3.3 Há aplicação de tratamentos silviculturais.

5.3.4 As práticas de exploração/colheita para cada espécie são compatíveis com seu respectivo potencial produtivo.

4.2 As práticas que envolvem a extração de óleos ou seivas dos troncos das árvores não têm impacto adverso sobre a viabilidade demográfica das espécies exploradas.

4.2.1 As árvores de copaíba submetidas anteriormente a extração de óleo não estão sujeitas a índices mais altos de mortalidade do que as árvores não submetidas a esta extração, na mesma população.

4.4 A extração de látex e resinas das árvores é feita de forma sustentável.

4.4.1 As populações locais de árvores produtoras de látex (por exemplo, Hevea, Brosimum, Couma e Manilkara spp.) são demograficamente viáveis.

República dos Camarões

1.5 Os PFNMs devem ser manejados de maneira sustentável.

1.5.1 Os PFNMs são conhecidos.

1.5.1.2 Conhecimento da capacidade de regeneração de cada espécie.

1.5.2 As técnicas de extração de PFNMs asseguram a sustentabilidade.

1.5.2.1 Existência de técnicas de conservação.

1.5.2.2 Ausência de técnicas destrutivas.

1.5.2.3 Tentativas de domesticar determinadas espécies. 
3.1 As técnicas de extração são sustentáveis.

3.1.1 A extração destrutiva de folhas, brotos de raiz, caules, raízes, galhos etc. é evitada para assegurar sua disponibilidade em épocas de necessidade.

3.2 A função da sazonalidade no uso dos recursos florestais e atividades de agropecuária é reconhecida.

3.2.2 Partes de plantas, incluindo a casca, são coletadas durante as estações apropriadas.

Indonésia

3.2. Aplica-se extração de baixo impacto.

3.2.1 A extração causa pouca perturbação.

3.2.2 O equipamento usado é apropriado ao conhecimento tecnológico local.

3.2.3 Há perturbação mínima nos hábitats de animais.

3.2.4 Os produtos florestais não-madeireiros são extraídos somente quando maduros.

6.1.2 Extração sustentável de PFNMs sob manejo da comunidade.

\section{3.e Intervenções produtivas 3 (PFNMs animais)}

A caça e a pesca são importantes para muitas comunidades que dependem da floresta; outros produtos animais, tais como mel, também podem ter a mesma importância. Observe que o tópico pesca também interage com manejo de recursos hídricos (ver 3.b) e todas as questões sobre PFNMs são relacionadas com biodiversidade. (ver 3.g). 
Brasil

4.5 A extração dos produtos animais usados na economia local não tem impacto negativo sobre as dinâmicas de população dos animais associados a esses produtos.

4.5.1 As técnicas de extração de mel não danificam as colméias ou as árvores com cavidades lenhosas nas quais elas estão associadas.

5.4 A pesca é realizada de maneira sustentável.

5.4.1 Existência de regras e padrões de pesca de baixo impacto.

3.1 A exploração dos recursos pesqueiros não levam à extinção demográfica ou econômica das populações de peixe ou tartarugas.

3.1.2 Os resenatórios naturais de peixe ou viveiros são mantidos e servem como fontes de imigrantes para partes dos rios ou cursos d'água onde os estoques de peixe têm sido super explorados.

3.1.3 Os peixes individuais capturados intencional ou acidentalmente estão além do tamanho crítico de maturidade reprodutiva para suas respectivas espécies.

3.1.5 A coleta de ovos de tartarugas (Podocnemis spp.) e de tartarugas fêmeas jovens e adultas nas praias é totalmente proibida.

2.1.6 Nenhuma caça comercial acontece dentro da comunidade.

República dos Camarões

1.3 Estratégias tradicionais visam a redução da pressão sobre animais silvestres, de acordo com as leis e regulamentos para assuntos de caça.

1.3.1 As leis e regulamentos sobre assuntos de caça são conhecidos de todos os participantes. 
1.3.2 Existem estratégias tradicionais que visam a proteção de determinadas espécies.

1.3.3 Métodos contra a caça clandestina são valorizados e aplicados.

1.3.4 Instrumentos e métodos destrutivos de caça são considerados ilegais.

1.3.5 A criação extensiva de animais domésticos permite reduzir a pressão sobre os animais silvestres.

4.2.4 A caça com armadilhas e a pesca são notavelmente reduzidas durante a estação seca.

Indonésia

3.3 Somente a caça de animais consumidos localmente e considerados pragas para os ladangs, é praticada.

3.3.1 A estação de caça é regulamentada.

\section{3.f Intervenções produtivas 4 (madeira)}

O manejo e a extração de madeira para uso doméstico são importantes para todas as comunidades que dependem da floresta. 0 manejo e a extração de madeira para comercialização é importante para muitas. Essa questão foi tratada nos testes realizados no Brasil e Indonésia.

Brasil

\subsection{As árvores madeireiras são extraídas de maneira sustentável.}

4.3.1 Não se observa qualquer declínio notável na densidade populacional de espécies madeireiras locais. 


\subsection{A exploração de madeira é realizada de maneira sustentável.}

5.2.2 Há aplicação de técnicas de baixo impacto.

5.2.3 Há aplicação de tratamentos silviculturais específicos (corte de cipós, eliminação de outras plantas competitivas) de acordo com o plano anual de operações.

Indonésia

6.1 Há integração sistemática da floresta natural no manejo comunitário dos recursos.

6.1.1 Há extração sustentável de madeira sob manejo da comunidade.

6.1.1.1 As pessoas conhecem os regulamentos.

6.1.1.2 A extração de madeira é monitorada pela autoridade.

6.1.1.3 Há organização local que coordena a extração de madeira.

6.1.1.4 Há distribuição equitativa de acesso aos recursos madeireiros entre os membros da comunidade.

6.1.1.5 Há replantio sistemático de árvores.

\section{3.g Saúde da floresta 1 (biodiversidade)}

A biodiversidade é tratada de maneira mais diferenciada pelas comunidades do que pelas abordagens convencionais comercial ou "científica" para C\&l. A biodiversidade se relaciona com questões sobre caça (ver 3.e) e outros PFNMs (ver 3.d). Também é essencial reconhecer e admitir a contribuição da biodiversidade para a agrofloresteria e outros cultivos da terra. 
Brasil

1.2 0 processo de fragmentação do habitat não compromete a manutenção da diversidade biológica no nível de paisagem florestal.

1.2.1 Os processos de fragmentação e conversão de habitats primários devem ser controlados, para não resultarem na erosão da biodiversidade e na extinção local ou regional de espécies.

2.1 A abundância de espécies de animais caçados de médio e grande porte é satisfatória tanto do ponto de vista ecológico como do ponto de vista sócio-econômico.

2.1.2 A abundância das populações de caça aumenta com a distância da fonte de pressão de caça (por exemplo, vila).

República dos Camarões

1.2 A biodiversidade é conservada.

1.2.1 A organização espacial preserva a biodiversidade.

1.2.2 As árvores úteis que estão se tornando raras são conhecidas e protegidas.

1.2.3 São plantadas espécies tradicionais úteis e raras.

1.2.5 Os animais selvagens sentem-se seguros e confortáveis.

1.3 A coexistência e/ou o co-desenvolvimento de sistemas de agricultura de pousio e de manejo de floresta natural mantém ou aumenta a biodiversidade.

1.3.1 O sistema de uso da terra é integrado, consistindo de uma variedade de sub-sistemas que asseguram uma biodiversidade global relativamente alta, em comparação à biodiversidade de qualquer um dos sub-sistemas.

1.3.2 Durante a preparação da área para plantio, as árvores valiosas são protegidas. 
Indonésia

1.2 Os impactos sobre a biodiversidade do ecossistema florestal são minimizados.

1.2.1 Espécies de plantas e animais em perigo de extinção são protegidas.

1.2.2 A caça comercial é controlada.

1.2.3 A produção de produtos florestais não-madeireiros é sustentável.

3.5 A diversidade de produtos agrossilviculturais no horto florestal é mantida.

3.5.1 A diversidade genética e de espécies é mantida.

\section{3.h Saúde da floresta 2 (estrutura e regeneração)}

A estrutura da floresta na paisagem, incluindo a agrofloresteria, é importante na manutenção de um meio ambiente propício à biodiversidade adequada (ver 3.f) e também na conservação de outras funções do ecossistema tais como a qualidade da água e a fertilidade do solo (ver 3.b). Os conceitos estruturais incluem: o padrão de floresta primária e secundária (enfatizado no conjunto de C\&l do Brasil - o qual também diz respeito ao mosaico geral da paisagem; ver 3.i); os aspectos horizontal e vertical da estrutura (enfatizados no conjunto de C\&l da República dos Camarões); e a capacidade de regeneração da floresta (como enfatizado pela equipe da Indonésia).

Brasil

1.1 Existe uma floresta contínua e estruturalmente inalterada, a qual oferece as mais satisfatórias condições ecológicas para a manutenção da biodiversidade local e para o uso sustentável dos recursos florestais.

1.1.1 Proporção de floresta primária e secundária dentro da FMC. 


\section{República dos Camarões}

\subsection{A regeneração natural é garantida.}

1.1.1 A distribuição horizontal de formas diferentes de plantas indicam haver dinamismo (diversidade) na estrutura da floresta.

1.1.1.1 Uma floresta densa e estável (em estágio de clímax) com uma estrutura semelhante àquela da floresta original da região.

1.1.1.2 Diversas formações de plantas (sucessão) desenvolvem-se nas zonas dedicadas à atividade agrícola durante o período de pousio.

1.1.2 A estrutura vertical da floresta primária não é perturbada.

1.1.2.1 Árvores de alturas diferentes contribuem para a estratificação do dossel da floresta (isto é, os topos das árvores distribuem-se em diferentes camadas).

1.1.2.2 Os diâmetros dos troncos variam.

1.1.2.3 O dossel mais alto é contínuo.

1.1.2.4 O chão da floresta é rico em mudas.

1.1.3 A distribuição e a freqüência de espécies são semelhantes àquelas da floresta original.

\section{Indonésia}

\subsection{A capacidade de regeneração natural do ecossistema florestal é garantida.}

1.3.1 Todas as fases de crescimento dos grupos de espécies são representadas.

${ }^{33} \mathrm{O}$ teor desse Indicador tem um significado bastante aberto. Uma frase que 0 tornaria mais preciso poderia ser: Todas as fases importantes de regeneração dos principais grupos ecológicos de espécies (i.e, associações) são representadas em toda a área da floresta manejada pela comunidade. 
1.3.2 Os hábitats de animais são mantidos ou restabelecidos. 1.3.3 A riqueza de espécies ${ }^{34}$ é mantida.

1.2.4 A estrutura da vegetação é mantida.

3.5.2 A estrutura da vegetação no horto florestal é similar à da floresta natural.

\section{3.i Diversidade da paisagem (fragmentação e mosaicos)}

Em todos os três locais, a questão da conversão de terras florestadas em outros usos da terra, e o possível risco resultante da fragmentação florestal, foi considerada importante. 0 estudo no Brasil captura esta questão da integridade da paisagem sob um Critério que reconhece a importância de um mosaico de diferentes hábitats na paisagem, e a necessidade da conversão para agricultura que seja sensível em relação ao mosaico total. $\mathrm{O}$ conjunto de $\mathrm{C} \& \mathrm{l}$ da Indonésia trata essa questão em termos específicos referindo-se ao sistema de horto florestal tembawang. A abordagem da República dos Camarões inclui um Indicador que trata explicitamente do processo de lidar com novos migrantes dentro da área como sendo uma indicação de que a conversão da floresta está sendo controlada.

\footnotetext{
${ }^{34} \mathrm{~A}$ referência neste Indicador (e outros a seguir) à qualidade da floresta sendo "mantida" obviamente baseia-se no pressuposto de que o estado "original" (ao qual ela está sendo comparada) é aceitável. Uma frase mais completa para esse tipo de indicador poderia incluir referência à qualidade que está sendo mantida em relação a um nível "original aceitável" ou "bem-regenerado".
} 
Brasil

1.3 A preservação de um mosaico de hábitats naturais mantém a complementaridade natural da ocorrência das espécies.

1.3.1 Entre os vários tipos de hábitats naturais que ocorrem na região, os mais raros (ou menores) na paisagem florestal são fortemente protegidos contra a conversão para agricultura.

1.3.2 As margens florestadas ao longo dos rios e dos igarapés são protegidas contra o desmatamento para presenvar suas funções hidrológicas e consenvar a biodiversidade. 0 mínimo legal de 50 metros de floresta mantidos ao longo dos rios e correntes d'água, é obedecido.

5.5.2 A derrubada de florestas primárias para uso agrícola está sendo evitada.

5.5.3 O tamanho das terras agrícolas não está aumentando anualmente.

República dos Camarões

2.1 0 preparo da terra para agricultura é grandemente restrito às terras em pousio e florestas secundárias.

2.1.1 Os períodos de pousio são longos o bastante para permitir a recuperação da fertilidade do solo.

2.2 A taxa de conversão de floresta natural é baixa.

2.2.1 A redução da área coberta por floresta natural durante um intervalo de tempo.

2.2.2 Provisões são feitas para reassentar novos imigrantes nas vilas sem causar muita pressão sobre as florestas naturais. 
2.2.2.1 As autoridades da vila consideram muito pouco ou até não consideram a possibilidade de assentar novos imigrantes diretamente nas áreas de floresta natural.

2.2.2.2 O número de novatos que estabelecem agricultura nas áreas de floresta natural é conhecido e controlado.

2.2.2.3 Tendências de migração.

Indonésia

3.1. As florestas naturais são mantidas por seu valor ambiental e de produção.

3.1.1 A produtividade das florestas naturais é mantida.

3.1.2 A conversão para ladangs é restringida.

3.6 A conversão para horto florestal é limitada.

3.6.1 A conversão é aceitável para conservar recursos.

3.6.2 A conversão é seguida pelo desenvolvimento de horto florestal em outras áreas.

1.1.5 A mudança drástica da cobertura do solo é evitada.

\section{Princípio 4. 0 meio ambiente externo é favorável ao MSFC}

Este princípio captura o apoio ideal de que a comunidade recebe para seu manejo sustentável de organizações externas tais como o Estado, seus órgãos e ONGs. Num acordo de manejo conjunto, pode ser uma boa idéia incluir aqui um critério explícito que trate da "saúde" da parceria entre a comunidade e seus parceiros de manejo colaborativo. Nos três locais de teste, não havia experiências de manejo colaborativo, e na realidade, o tratamento das questões sobre organizações externas foi muito variável. Essas questões são aqui tratadas em quatro seções:
a. Relacionamentos com terceiros
b. Estruturas política e legal (excluindo posse)
c. Economia
d. Educação e informação 


\section{4.a Relacionamentos com terceiros}

O relacionamento com outros atores é crucial para a sustentabilidade do manejo. 0 enfoque sobre o relacionamento com terceiros foi muito diferente nos três locais de teste (ver Quadro 4). A equipe do Brasil trata principalmente do relacionamento com os empregadores dos membros da comunidade; a equipe da República dos Camarões trata dos relacionamentos com o estado e ONGs; a equipe da Indonésia somente menciona os relacionamentos com outras comunidades. De um modo geral, esses relacionamentos demonstram a necessidade de haver boa comunicação entre a comunidade e terceiros.

\section{Brasil}

6.5 Os direitos a as condições de trabalho são adequados, ou pelo menos considerados justos, nas relações empregatícias voltadas para 0 uso dos recursos agroflorestais entre os membros da comunidade e atores externos.

6.5.1 Os salários e benefícios são apropriados no que se refere às tarefas desempenhadas.

6.5.2 Ausência de pagamento de salário inferior e de exploração de trabalho infantil e feminino.

6.5.3 As condições de trabalho são apropriadas e obedecem à legislação existente.

6.5.4 Ausência de trabalho escravo.

6.5.5 O direito à organização de classe é garantido.

6.5.6 O direito de negociação coletiva entre a comunidade, seus representantes e os atores externos é garantido. 
Quadro 4. Relações com terceiros: experiências extraídas dos três locais de teste do CIFOR.

\section{Vilas de São Pedro e Cachoeira do Maró, Pará Brasil}

Durante a década passada, grandes áreas de floresta adjacentes ao rio Arapiuns e seus afluentes, onde essas vilas estão localizadas, foram exploradas intensivamente por empresas madeireiras. A atividade de uma empresa afetou profundamente São Pedro e teve um pequeno impacto em Cachoeira do Maró. Os habitantes de São Pedro experimentaram um grande crescimento e fracasso, com uma explosão de oportunidades de emprego oferecidas pela empresa, e sofreram com a redução dos estoques de madeira de suas terras. Essa novidade chegou até às comunidades rio acima (na direção da mais importante rota de exploração planejada pela empresa), as quais subseqüentemente uniram-se à vila de São Pedro para expulsar todas as empresas madeireiras da região. O Sindicato dos Trabalhadores Rurais e outras ONGs locais estão ajudando muitas comunidades ao longo da bacia do rio Arapiuns, incluindo São Pedro e Cachoeira do Maró, a desenvolverem uma proposta para a criação de uma reserva extrativista oficial.

\section{Vilas de Eyek II e Akak/Bitetele, Endom, República dos Camarões}

Os habitantes de ambas as vilas pertencem à Federação Comunitária de Grupos de Vilas SOLIDAM (Solidarité pour le developpment des villages d'Akak à Melan). Criada em 1990, a SOLIDAM tem aproximadamente 800 membros associados em 11 vilas vizinhas, que cobrem uma área de aproximadamente $11 \mathrm{~km}$ por $35 \mathrm{~km}$. A SOLIDAM tem recebido auxílio de várias ONGs da República dos Camarões, e mais recentemente do Programa GIF do Banco Mundial e da WWF da República dos Camarões, para desenvolver projetos ambientais, agrícolas, de saúde e de geração de renda.

\section{Vilas de Bedigong e Darok, Kalimantan ocidental, Indonésia}

Estas vilas estão entre um grupo de comunidades que pertencem a uma organização cooperativa fundada com auxílio do Projeto de Desenvolvimento Florestal Social, uma iniciativa de colaboração entre o Ministério da Silvicultura Indonésio e o governo alemão. A cooperativa está desenvolvendo empresas florestais de pequena escala e está a ponto de implementar um plano de manejo florestal para uma área de floresta natural adjacente à Bedigong, a qual pertence à Darok. Os custos e os benefícios resultantes serão distribuídos entre os participantes de todas as comunidadesmembros. A administração da cooperativa eventualmente tornar-se-á de responsabilidade total das comunidades membros. 
República dos Camarões

3.4 0 membros da vila participam com outros atores na proteção dos recursos madeireiros em suas comunidades.

3.4.1 As comunidades locais tomam medidas para proteger ativamente suas espécies madeireiras contra a exploração por forasteiros que podem ou não estar sendo apoiados pelo órgão público florestal.

5.5.2 Estado e ONGs auxiliam as comunidades no manejo florestal sustentável.

7.1.3 Existe um sistema de diálogo na comunidade para negociação/discussão das questões sobre manejo florestal com órgãos públicos e ONGs.

Indonésia

4.3 Há consenso sobre os direitos de propriedade entre as comunidades.

4.3.1 Há um mecanismo para resolução de conflitos fora dos limites da comunidade.

4.3.1.1 Casos de conflito de terra entre comunidades.

4.3.1.2 Casos de resolução de conflitos

4.3.1.3 Conflitos são resolvidos por mecanismos para resolução de conflitos.

\section{4.b Estruturas política e legal (excluindo posse)}

As estruturas políticas de apoio do governo e as estruturas legais podem prover os gestores comunitários de poder para tratar com terceiros, e fornecer ajuda importante no tratamento dos conflitos difíceis. Os testes realizados na República dos Camarões e no Brasil revelaram a importância do reconhecimento legal do manejo comunitário. Os testes na Indonésia e no Brasil também revelaram a importância da 
participação no planejamento de programas de desenvolvimento e suas políticas. Esta questão relaciona-se com a questão da autoridade da comunidade para manejar (ver 1.d),com a do manejo do conflito (ver 1.c) e com a da posse individual (ver 2.d).

Brasil

\subsection{A comunidade exerce o direito de se organizar social e politicamente.}

6.2.2 Aplicação de procedimentos legais na resolução de conflitos referentes aos recursos agroflorestais que envolvem atores internos e/ou externos (vizinhos, empresas madeireiras, outras comunidades, patrões, etc.).

6.2.2.a Levantamento de registros legais de conflitos relacionados ao uso e posse da terra e dos recursos agroflorestais, e suas resoluções.

6.2.2.c A população local é compensada por danos causados por terceiros aos seus recursos agroflorestais.

6.6.1.e A história da participação da comunidade na definição de políticas públicas de impacto local e regional.

República dos Camarões

5.5. 0 manejo comunitário dos recursos florestais é compatível com as metas prioritárias de manejo e desenvolvimento florestal do Estado.

5.5.1 Potencial do sistema legal para incluir as aspirações das comunidades locais no manejo florestal.

5.5.1.1. Conteúdo da política e regulamento florestal.

5.5.1.2. Mudanças na jurisprudência.

7.1.2.1 Os tribunais oficiais de justiça reconhecem as decisões dos sistemas tradicionais legais. 


\section{Indonésia}

\subsection{Os planos e programas de desenvolvimento do governo} consideram os sistemas locais de posse e os sistemas de uso da terra.

4.2.1 O sistema local de uso da terra é parte de algum programa de desenvolvimento.

4.2.1.1 Há total participação da comunidade local no planejamento e na implementação.

4.2.1.3 Igualdade de gêneros em todos os processos.

4.2.1.4 Há participação nas tomadas de decisões sobre divisão dos benefícios.

4.2.1.5 Todas as categorias da comunidade têm participação nos benefícios.

\section{4.c Economia}

O setor econômico externo foi incluído em todos os três locais. Tratou principalmente da existência de mercados conhecidos para produtos florestais manejados pela comunidade. Outras questões econômicas tratadas são: subsídios e transporte; e investimento em infraestrutura (ver 2.b).

35 Esta é uma expressão especialmente ampla da importância da eqüidade dos gêneros (i.e., pelo fato de que é "igualdade" ao invés de eqüidade, e "todos" ao invés de "quando possível"). As expressões mais comuns dessa questão são formuladas assim: "mulheres e homens participam nos ....processos ou "há equilíbrio de gêneros na participação em processos". 


\section{Brasil}

5.7.2 Conhecimento de mercados para produtos florestais (e agrícolas).

5.7.3 Existência de mecanismos da comunidade para comercialização de produtos.

5.7.3.1 Infraestrutura e transporte acessíveis às comunidades (barcos, caminhão, estradas etc.).

5.7.3.2 Existência de "cantinas" ou "entrepostos" administrados pela comunidade, nas quais se vendem produtos florestais dos agricultores e se compram insumos para revenda a preço de custo, ou quase.

5.7.4 Conhecimento dos custos de produção (custo de depreciação de equipamento, reinvestimentos, manutenção).

6.7.3 A comunidade depende de subsídios externos fornecidos por ONGs, organizações religiosas e ou pelo governo.

\section{República dos Camarões}

5.2.1.2 Conhecimento do valor de mercado dos recursos florestais.

Indonésia

6.3.5 Existem sistemas de apoio à agricultura.

6.3.5.1 Insumos disponíveis para a agricultura.

6.3.5.2 Crédito agrícola disponível.

6.2.3.3 Existe mercado para látex.

3.4.1.1. Existe mercado para produtos do horto florestal. 


\section{4.d Educação e informação}

Na Indonésia, a educação foi considerada vital e foi totalmente elaborada como um conjunto de C\&l. Nos outros sítios a educação foi menos mencionada. Essa questão relaciona-se com a questão da sabedoria e conhecimento (ver 2.c). Nos Verificadores há referências regulares a fontes de informação tais como documentos, mapas e informações do censo. A disponibilidade de informação pode ser considerada uma questão importante, por si só. Outra área que a equipe da Indonésia achou importante foi a "extensão" na forma de treinamento e assistência técnica na adaptação do sistema de manejo do ladang.

\section{Brasil}

5.1.2.2 Mapeamento dos "principais usos da terra" com o uso de mapas e imagens de satélite.

5.5.2.2 Mapeamento da cobertura vegetal, nos diferentes anos, por meio de imagens de satélite.

6.7.4.c Porcentagem de crianças em idade escolar com presença regular na escola.

\section{República dos Camarões}

5.5.2.3 Programas apropriados de desenvolvimento da educação. 


\section{Indonésia}

\subsection{A educação formal e a não formal favorecem a sustentabilidade da floresta.}

7.1.1 Acesso público a todos os níveis educacionais.

7.1.2 Conteúdo curricular local voltado à construção da consciência ambiental.

7.1.2.1 Aulas sobre o meio ambiente.

7.1.2.2 Aulas sobre os sistemas locais de uso da terra.

6.3.4 Há treinamento ${ }^{36}$ em agricultura permanente.

7.1.3.4 Treinamento dos membros da comunidade em problemas ambientais.

7.1.3.5 Treinamento em atividades de geração de renda.

7.1.3.6 Troca de informações com fontes de fora da comunidade.

6.2.4 Há política e atividade para racionalizar o sistema de corte e queima.

6.2.4.1 Uso do conhecimento local

6.2.4.2 Mobilização de conhecimento científico.

6.2.4.4 Experimentos de campo.

\footnotetext{
${ }^{36}$ Alguns conjuntos de $\mathrm{C} \&$ preferem não valorizar a existência do treinamento como um Indicador ou Verificador pelo fato dele ser considerado somente um insumo. Em outras palavras, a existência de um curso de treinamento pode ou não, de fato, indicar uma contribuição para a sustentabilidade - pois vai depender da qualidade do curso e de quem participa - se ocorrem mudanças como resultado do curso. Isto significa que um Indicador ou Verificador mais preciso (embora desafiador) pode fazer mais alusão aos impactos de cursos de treinamento/implementação das habilidades aprendidas, etc.
} 


\section{Solicitação de Contribuições}

Esperamos que este guia forneça um ponto de partida útil para experiências novas e bem-sucedidas de monitoramento de MCF para sustentabilidade. Consideramos este guia um começo e também um trabalho em andamento; caso você o use, seremos gratos por receber informações sobre suas experiências, assim como contribuições e sugestões.

Bill Ritchie e Mandy Haggith podem ser contatados no Worldforests.

Endereço: 95 Achmelvich, Lochinver, Sutherland IV27 4JB, SCOTLAND

Correio eletrônico: bill@worldforests.org

Cynthia McDougall (ou qualquer pessoa do Programa Local People, Devolution and Adaptive Co-Management do CIFOR) pode ser contactada no CIFOR via Correio eletrônico: c.mcdougall@cgiar.org ou cifor@cgiar.org

Também podemos ser contactados via correio no endereço postal: Programa Local People, Devolution and Adaptive CoManagement

Centro para Pesquisa Florestal Internacional

P.O. Box 6596 JKPWB, Jakarta 10065, Indonesia

tel:+62 (251) 622622 fax: +62 (251) 622100 


\section{Referências}

Todas as referências a seguir podem ser obtidas através de solicitação às editoras (algumas podem cobrar os custos com postagem). Caso necessite de auxílio adicional, os endereços de algumas dessas editoras estão disponíveis no final deste manual. Algumas das referências citadas também estão disponíveis na internet; neste caso, seus endereços na internet (URL) são fornecidos. Há também muitos outros livros, publicações em revistas científicas e relatórios sobre manejo comunitário de florestas (muitos dos quais são citados em todo o relatório dos três testes de C\&l para MCF por Burford de Oliveira et al. (1999).

\section{Referências dos testes de campo de C\&l para MCF do CIFOR (que serviram de base para este manual):}

Burford de Oliveira, N., Shiembo, P., Tiani, A. and Vabi, M. 1998. Developing and testing Criteria and Indicators for the sustainability of Community Managed Forests in the SOLIDAM zone, Central Province, Cameroon. CIFOR Draft Field Test Report.

Burford de Oliveira, N., Ritchie, B., McDougall, C., Hartanto, H. and Setyawati, T. 1999. Developing Criteria and Indicators of Community Managed Forests as assessment and learning tools: Objectives, methodologies and results. CIFOR Project Report.

Burford de Oliveira, N. 1999. Community participation in developing and applying Criteria and Indicators of sustainable and equitable forest management. CIFOR Project Report.

Mattos, M.M. with Burford de Oliveira, N., Silva, L., Peres, C. and Murrieta, R. Relatório final do teste do Brasil: Desenvolvendo e testando critérios e indicadores de sustentabilidade para manejo florestal comunitário. 1998. CIFOR Field Test Report. (Somente em Português). 
Maryani, R., Sunito, S., Hatta,G. and Burford de Oliveira. 1998. Developing Criteria and Indicators for Community Managed Forests - Indonesian test sites. CIFOR Field Test Report.

\section{Referências dos C\&I:}

CIFOR C\&I Team. 1999. The CIFOR Criteria and Indicators Toolbox Series. CIFOR, Bogor, Indonesia.

(A série é direcionada a C\&l para florestas comerciais, e atualmente contém os seguintes instrumentos:

1. Guidelines for Developing, Testing and Selecting Criteria and Indicators for Sustainable Forest Management

2. The CIFOR Criteria and Indicators Generic Template

3. CIMAT (Criteria and Indicators Modification and Adaptation Tool) (on CD-ROM only)

4. The CIFOR Criteria and Indicators Resource Book Database (on CD ROM only)

5. The BAG (Basic Assessment Guide for Human Well-being)

6. The Grab Bag: Supplementary Methods for Assessing Human Well-being

7. Scoring and Analysis Guide for Assessing Human Well-being

8. Who Counts Most? Assessing Human Well-being in Sustainable Forest Management

9. Guide for Applying Multi-Criteria Analysis to the Assessment of Criteria and Indicators)

Herweg, K., Steiner, K., Slaats, J. (eds.). 1998. Sustainable Land Management - Guidelines for Impact Monitoring (Workbook and Toolkit). Centre for Development and Environment, Berne, Switzerland.

Lammerts van Bueren, E.M. and Blom, E. 1997. Hierarchical framework for the formulation of sustainable forest management standards. Principles, Criteria and Indicators. The Tropenbos Foundation, Wageningen, the Netherlands. 
Mendoza, G., and Macoun, P. with Prabhu, R., Sukadri, D., Purnomo, H. and Hartanto, H. 1999. Guidelines for applying multi-criteria analysis to the assessment of Criteria and Indicators. CIFOR C\&I Toolbox Series, Tool No 9.

Prabhu, R., Colfer, C.J.P. and Dudley, R.G. 1999. Guidelines for developing, testing and selecting Criteria and Indicators for sustainable forest management. CIFOR C\&I Toolbox Series, Tool No 1.

Prabhu, R., Colfer, C.J.P., Venkateswarlu, P., Tan, L.C., Soekmadi, R. and Wollenberg, E. 1996. Testing Criteria and Indicators for the sustainable management of forests: Phase 1 Final Report. CIFOR.

Salim, A. and Colfer, C.J.P. with McDougall, C. 1999. Scoring and analysis guide for assessing human well-being. CIFOR C\&l Toolbox Series, Tool No 7.

Stevens, P. 1997. Measuring the sustainability of forest village ecosystem concepts and methodologies: A Turkish example. CSIRO, Australia.

Stork, N.E., Boyle, T.J.B., Dale, V., Eeley, H., Finegan, B., Lawes, M., Manokaran, N., Prabhu, R. and Soberon, J. 1997. Criteria and Indicators for assessing the sustainability of forest management: Conservation of biodiversity. CIFOR Working Paper 17.

\section{Consulte também:}

Página na internet da Forest Stewardship Council, especialmente sua seção sobre Princípios e Critérios de sustentabilidade do manejo florestal (FSC standards). http://fscus.org/fscus2a12.html

Página na internet de C\&l do CIFOR para as ferramentas da Série manuais de C\&l (para florestas comerciais) e outras publicações:http:// www.cifor.cgiar.org/CimatWeb/ie4/publication_related_1.htm. 


\section{Referências dos métodos e instrumentos de participação:}

Bruce, J.W. 1989. Community forestry: rapid appraisal of tree and land tenure. FAO Community Forestry Note 5.

Case, D'A.D. 1990. The Community's Toolbox: The idea, methods and tools for participatory assessment, monitoring and evaluation in community forestry. FAO Community Forestry Field Manual 2.

Colfer, C.J.P. with Prabhu, R., Gunter, M., McDougall, C., Miyasaka-Porro, N. and Porro, R. 1999. Who counts most? Assessing human well-being in sustainable forest management. CIFOR C\&l Toolbox, Tool No. 8.

CIFOR Methods Testing Team. 1999. The BAG: Basic Assessment Guide for human well-being. CIFOR C\&l Toolbox, Tool No. 5.

Freudenberger, K.S. 1994. Tree and land tenure rapid appraisal tools. FAO Community Forestry Field Manual 4.

Thomson, J.T. and Freudenberger, K.S. 1997. Crafting institutional arrangements for community forestry. FAO Community Forestry Field Manual 7.

\section{Referências básicas sobre MCF:}

Arnold, J.E.M. 1992. Community forestry: Ten years in review. FAO Community Forestry Note 7.

Arnold, J.E.M. 1998. Managing forests as common property. FAO Forestry Paper 136.

Edmunds, D. and Wollenberg, E. Forthcoming. A Strategic Approach to Multistakeholder Negotiations. Paper accepted for publication in Development and Change.

Messerschmidt, D.A. et al. 1993. Common forest resource management: Annotated bibliography of Asia, Africa and Latin America. FAO Community Forestry Note 11. 
Ostrom, E. 1999. Self-governance and forest resources. CIFOR Occasional Paper No. 20. www.cgiar.org/CIFOR/publications/ occpaper/occpaper20/ OP-20.pdf

Poffenberger, M. (ed.). 1998 onwards. Communities and forest management regional profile series. Working Group on Community Involvement in Forest Management (WG-CIFM).

Thomson, J.T. 1992. A framework for analyzing institutional incentives in community forestry. FAO Community Forestry Note 10.

Verolme, H.J.H., and Moussa, J. (eds.). April 1999. Addressing the underlying causes of deforestation and forest degradation case studies, analysis and policy recommendations. Biodiversity Action Network, Washington DC. www.bionet-us.org

Warner, K. 1999. Shifting cultivators: Local technical knowledge and natural resource management in the humid tropics. FAO Community Forestry Note 8. 


\title{
Alguns endereços úteis para contatos relacionados a MCF
}

\section{Referências para monitoramento e relatórios sobre MCF}

\author{
Para relatórios produzidos pelo CIFOR, contate: \\ CIFOR (Center for International Forestry Research) \\ P.O. Box 6596 JKPWB, Jakarta 10065, Indonesia \\ Tel: +62-251-622-622; Fax: +62-251-622-100 \\ Correio eletrônico: cifor@cgiar.org \\ http://www.cifor.cgiar.org
}

Para relatórios produzidos pela FAO, contate:

Forests, Trees and People Programme

Community Forestry Unit, Forestry and Planning Division

FAO (Food and Agriculture Organisation of the United Nations)

Viale delle Terme di Caracalla, Rome 00100, Italy

Fax: (39-6) 5705-5514

Correio eletrônico: ftpp@fao.org

http://www.fao.org/waicent/faoinfo/forestry/fon/fonp/ cfu/default.htm

\section{Para relatórios produzidos pela WG-CIFM, contate:}

Working Group on Community Involvement in Forest Management

The World Conservation Union - IUCN

Rue Mauverney 28, CH-1196 Gland

Switzerland

Tel:+41-22-999-0001; Fax:+41-22-999-0025

Correio eletrônico: spr@hq.iucn.org 


\section{Outras organizações-chave envolvidas em monitoramento de MCF}

\section{IDS}

Participation Group

Institute of Development Studies

University of Sussex, Brighton BN1 9RE, UK

Tel: +44 1273 606261; Fax: +44 1273621202

Email: participation@ids.ac.uk

http://www.ids.ac.uk/ids/particip/infoexch.html

\section{IISD}

International Institute of Sustainable Development

161 Portage Avenue East, 6th Floor

Winnipeg, Manitoba, R3B OY4, Canada

Tel: +1 204-958-7700; Fax: +1 204-958-7710

Email: info@iisd.ca; URL: http://iisd.ca/

\section{RECOFTC}

The Regional Community Forestry Training Center Kasetsart University, PO Box 1111, Bangkok 10903, Thailand

Tel: +66-2-940-5700; Fax: +66-2-561-4880

Email: ftcsss@nontri.ku.ac.th; URL: http://recoftc.org/

\section{The Forest Stewardship Council}

PO Box 10

Waterbury, Vermont 05676, USA

Tel: +1-802-244-6257; Fax: +1-802-244-6258

E-mail: info@fscus.org

http://fscus.org/fscus2.html

\section{The Tropenbos Foundation}

Lawickse Allee 11

P.O. Box 232, 6700 AE Wageningen

The Netherlands

Tel: +31 317 426262; Fax: +31 317423024

Email: tropenbos@iac.agro.nl

http://www.bib.wau.nl/tropbos/ 


\section{Apêndice 1}

\section{Resumo das questões e comparações entre os locais de teste de C\&l para MCF do CIFOR.}

Este resumo é baseado nos testes de campo do CIFOR e, portanto, considera os quatro agrupamentos originais (e mais "científicos") de C\&l - Ecologia, Manejo Florestal, Social e Participação Comunitária.

\section{C\&l de Ecologia}

Os C\&l sobre integridade do ecossistema, biodiversidade, manejo de bacias hidrográficas, estrutura da floresta e regeneração natural foram desenvolvidos por todos os ecólogos das equipes de teste. O subgrupo de C\&l de ecologia da Indonésia enfatiza questões sobre solos e proteção de espécies em perigo de extinção. O subgrupo de C\&l de ecologia da República dos Camarões detalha mais as estratégias de caça e os impactos dos sistemas agrícolas (incluindo métodos de controle de pragas) na sustentabilidade da floresta. Além disso, ele inclui um número bastante alto de C\&l para avaliar as práticas de pesca locais que, no local de testes da República dos Camarões, são de especial significado econômico, especialmente para as mulheres.

Encontra-se, porém, uma quantidade maior de C\&l sobre pesca nos grupos de C\&l de ecologia e de manejo florestal do Brasil. A caça é tratada com mais detalhe pelo grupo de C\&l do Brasil, o qual também inclui um número comparativamente grande de

\footnotetext{
${ }^{37}$ Esta seção foi extraída diretamente de Burford de Oliveira (1999).
} 
C\&l para investigar padrões e processos de fragmentação florestal, qualidade da água e função de conservação das reservas florestais. Os C\&l do Brasil e da República dos Camarões abordam a avaliação da caça de maneiras diferentes. 0 primeiro discorre sobre quantificação enquanto 0 último enfatiza métodos e processos.

As causas e incidências de incêndios florestais são substancialmente elaboradas pelos subgrupos de C\&l de ecologia do Brasil e de manejo florestal da Indonésia e Brasil. Complexos de C\&l para a avaliação local dos métodos de coleta e de processamento de PFNMs aparecem nos subgrupos de C\&l de ecologia e de manejo florestal do Brasil e República dos Camarões, e também no subgrupo de manejo da Indonésia.

\section{C\&l de manejo florestal}

C\&l para estratégias de produção sustentável aparecem em todos os subgrupos de C\&l de manejo. As referências mais explícitas sobre a adaptação de métodos de manejo ao potencial dos recursos aparecem nos subgrupos da Indonésia e Brasil - no caso brasileiro, a adaptação é examinada através da questão do zoneamento. Os C\&l de manejo da Indonésia enfatizam tecnologias florestais usadas localmente, um assunto abordado como uma perspectiva complementar pelo Subgrupo de C\&l sociais da Indonésia. Referências às tecnologias são comparativamente ineficientes em conjuntos de C\&l de outro país. O subgrupo de C\&l de manejo da Indonésia também fornece os C\&l de sistemas agroflorestais mais detalhados, presumivelmente por causa da importância econômica, amplamente reconhecida, dos hortos tembawang e de seringueiras, que foram estabelecidos nas comunidades onde foram realizados os testes. 
Os subgrupos de C\&l de manejo da República dos Camarões e do Brasil ressaltam a avaliação dos métodos de extração destrutivos. Com exceção do subgrupo de C\&l de manejo da República dos Camarões, este é um complexo de C\&l sobre integração de diversas atividades econômicas dependentes da floresta. Este subgrupo também inclui C\&l sobre tendências demográficas e sobre conversão de floresta para agricultura, bem como um número de C\&l para avaliar a importância dos sistemas agrícolas para conservação da floresta e da biodiversidade. Essas questões são tratadas de pontos de vista um pouco diferentes pelo subgrupo de C\&l de ecologia da República dos Camarões. Os C\&l de manejo da Indonésia não fazem referência à conversão de floresta natural, mas fazem indagações sobre a conversão de agroflorestas para agricultura. Os subgrupos de C\&l de manejo da República dos Camarões e do Brasil fornecem vários C\&l sobre o cronograma e a freqüência de intervenções e atividades de extração/coleta na floresta.

No subgrupo de C\&l de manejo do Brasil aparecem vários C\&l sobre comercialização de produtos florestais e cooperativas de produtores. Também aparece um complexo de C\&I para avaliar as atividades florestais comunitárias de fiscalização e monitoramento. Essas últimas questões também são tratadas parcialmente em alguns dos C\&l de manejo da República dos Camarões sobre a resistência das comunidades à apropriação de seus recursos florestais por grupos externos de interessados.

Comparado aos outros subgrupos de manejo, o do Brasil dá ênfase especial à avaliação do manejo florestal para produção de madeira, incluindo C\&l sobre questões tais como: ciclos de corte, queda direcional, altura do toco da árvore, tratamentos de liberação e estradas de exploração. Este subgrupo de C\&l enfatiza estratégias de avaliação do manejo em termos de suas 
implicações financeiras. Isso contrasta com vários dos C\&I de manejo da Indonésia que priorizam mais explicitamente as considerações ecológicas na avaliação da extração madeireira. A comparação dos grupos de C\&l de manejo do Brasil e da República dos Camarões revela outra dicotomia com o conteúdo do primeiro, que enfoca a integração do mercado, e do segundo, que enfoca a estabilidade de um sistema econômico tradicional mais fechado, baseado principalmente em transações recíprocas.

\section{C\&l Sociais}

Todos os subgrupos sociais contêm C\&l sobre segurança de posse e direitos de usufruto da terra, acesso aos recursos florestais, processos de tomada de decisão, mecanismos para resolução de conflitos, bem como C\&l que tratam direta e indiretamente dos padrões de distribuição dos custos-benefícios do manejo florestal. Os subgrupos de C\&l sociais do Brasil e, em menor proporção, os da Indonésia, incluem C\&l que se referem explicitamente aos recursos de propriedade comum. Todos os subgrupos de C\&l sociais investigam a importância dos sistemas de conhecimento local sobre os métodos atuais de manejo florestal, incluindo numerosas referências à reprodução e desenvolvimento do conhecimento. Muitos dos C\&l sociais da Indonésia sobre conhecimento se referem mais à quantidade $\mathrm{e}$ conteúdo da educação formal. Eles objetivam explorar se, e como o conhecimento formal ajuda a reproduzir e desenvolver os sistemas de conhecimento tradicional - uma linha de investigação considerada importante, visto que mais e mais práticas tradicionais vão se tornando obsoletas, e o conhecimento tradicional possui, freqüentemente, relevância limitada na introdução de novas idéias e tecnologias. 
Os C\&l sociais do Brasil sobre direitos dos trabalhadores, condições de trabalho e relações de trabalho fornecem um bom complemento para os seus C\&l de manejo sobre integração ao mercado. Eles incluem a história da distribuição de emprego e suas relações com atores externos, a legislação trabalhista, e o trabalho escravo. Não apareceu nenhuma menção direta a essas questões em qualquer um dos outros subgrupos. Os C\&l sociais do Brasil sobre organização política comunitária também representam um enfoque não encontrado em qualquer outro subgrupo. É entre os C\&l sociais do Brasil que encontramos as referências mais explícitas à dependência da floresta, incluindo formas de dependência direta e indireta. Também nos C\&l que se referem a assuntos de dependência da floresta há temas tão diversos quanto planejamento familiar, padrões de consumo de alimentos, proteção de sítios de herança cultural, e transmissão de conhecimento tradicional. Muitas dessas questões são tratadas nos conjuntos de C\&l dos outros países, mas definidas em diferentes contextos de C\&I pela organização das questões na estrutura hierárquica.

A compatibilidade das leis e políticas públicas com as estratégias de manejo e controle locais é mais completamente explorada pelos C\&l sociais da República dos Camarões. Alguns C\&l nos subgrupos de C\&l sociais do Brasil e Indonésia, porém, tratam de assuntos similares tais como: de que modo as políticas do governo relacionam-se às formas de uso da terra local, e a participação da comunidade no planejamento de programas de desenvolvimento mantidos pelo governo.

\section{C\&l sobre participação da comunidade}

O grupo de C\&l da Indonésia contém os C\&I mais detalhados e explícitos para avaliar a participação dos membros da comunidade nos assuntos comunitários, nas disputas políticas e nas iniciativas 
governamentais de desenvolvimento comunitário. Todavia, vários relatos referentes à ação e colaboração coletiva entre os membros da comunidade aparecem nos subgrupos de C\&l sociais e de manejo florestal da República dos Camarões. 0 subgrupo de C\&l sociais do Brasil inclui alguns C\&l sobre participação da comunidade no planejamento e no monitoramento das intervenções de manejo. Os grupos de C\&l de todos os países incluem vários $c \&$ que se referem a diferentes grupos, como por exemplo aqueles definidos de acordo com interesses, idade ou gênero. Por outro lado, somente poucos relatos destacam particularmente um grupo de interesse ou um grupo minoritário; e quase todos que 0 fazem, enfocam a participação da mulher em debates. Esse fato criou alguma preocupação com respeito à capacidade dos conjuntos de C\&l de capturarem os interesses e necessidades especiais de grupos minoritários, grupos oprimidos ou grupos pouco representados na comunidade. 


\section{Apêndice 2}

\section{Conjuntos e diretrizes usados como base pelas equipes de testes de C\&l para MCF}

\section{Os conjuntos e as diretrizes usados como base pelas equipes de testes de C\&I para MCF foram os seguintes:}

Biodiversity Support Program. 1993. Guiding principles and recommendations for African integrated biodiversity conservation and sustainable development. In: Biodiversity Support Program, African biodiversity: Foundation for the future. Professional Printing, Beltsville, Maryland.

CIFOR. 1997. Possible source themes for Criteria and Indicators for Community Managed Forests. Unpublished.

FAO. 1995. Indicators of sustainability. In: Resource management for upland areas in Southeast Asia.

Forest Stewardship Council. 1996. Principles and Criteria for forest management.

Lammerts van Bueren, E. and Blom, E. 1997. Hierarchical framework for formulation of sustainable forest management standards. The Tropenbos Foundation, Waginengen, The Netherlands.

Lembaga Ekolabel Indonesia (LEI). The Criteria and Indicators for sustainable natural forest management on Forest Management Unit level. LEl webpage at http://www.iscom.com/ ekolabel.

Pierce, A. 1996. Issues pertaining to the certification of non-timber forest products. A Forest Stewardship Council Discussion Paper, 1 May. Forest Stewardship Council. 
Prescott-Allen, R. 1996. Barometer of sustainability. In: IUCN, An approach to assessing progress towards sustainability. Tools and Training Materials Series 2-8317-0342-5.

Prabhu, R. et al. 1996. Sets of Principles, Criteria, Indicators and Verifiers resulting from tests conducted in Ivory Coast and Brazil. In: Testing Criteria and Indicators for the sustainable management of forests: Phase 1 Final Report. CIFOR.

Smart Wood. 1995. Standards for non-timber forest products certification: The case of Brazil nuts (Bertholletia excelsa h.b.k.) and rubber (Hevea brasiliensis), Version \# 2.0, 16th August Richmond, Vermont.

Stevens, P. 1997. Measuring the sustainability of forest village ecosystem concepts and methodologies: A Turkish example. CSIRO, Australia.

Zimmermann, R. 1992. Provisional assessment guidelines used in connection with smallholder eco-timber projects in Papua New Guinea (November- December). Smart Wood, Richmond, Vermont.

Zweede, J., Kressin, J., Mesquita, R., Silva, J.N.M., Viana, V.M. and Colfer, C. 1995. Final Report - Test Brazil October 22 November 21, 1995. CIFOR Project on testing Criteria and Indicators for the sustainable management of forests. CIFOR, Bogor, Indonesia. 
Quadro 2. Visão geral do "processo de filtragem" de C\&l para MFC das equipes de testes do CIFOR.

\section{Filtro 1.}

Nesta fase inicial, cada membro da equipe selecionou C\&l relevantes dentre os Conjuntos Básicos de C\&l que Ihes foram apresentados e propuseram C\&l adicionais que the pareceram importantes. Este primeiro processo de filtragem individual resultou em três sub-grupos de C\&l preliminares (um para cada disciplina: ecologia, sócioeconomia e técnicas de manejo).

\section{Filtro 2.}

Este filtro consistiu de uma revisão, feita por uma equipe interdisciplinar, dos sub-conjuntos de C\&l produzidos pelo Filtro 1. Os membros da equipe estavam cientes de que os conjuntos produzidos durante esse filtro poderiam não tratar de todas as questões que afetam a sustentabilidade de forma crítica nos seus locais de teste e/ou das questões priorizadas pelos membros da comunidade local. Portanto, foi-Ihes pedido que mantivessem essas necessidades em mente até o próximo filtro (que aconteceria no local de teste).

\section{Filtro 3}

O terceiro filtro foi o teste de campo dos C\&l. Ele foi realizado pelas equipes de teste, que consultaram os grupos florestais de interesse dentro da comunidade local por um período de 10 a 14 dias. Durante os testes de campo, as equipes foram encorajadas a aproveitar sua experiência profissional em Avaliação Rural Participativa (ARP) e outras técnicas para conseguir a contribuição ativa dos membros da comunidade no desenvolvimento e seleção dos C\&l.

Filtro 4.

O último filtro consistiu no exame dos C\&l pelos participantes durante uma reunião de trabalho (workshop). Pediu-se aos participantes do workshop que avaliassem a aplicabilidade dos C\&l selecionados nas "condições" dos locais de teste, e ao mesmo tempo, mantivessem na memória as características de outro MCF que eles conheciam. 

"Sistemas comunitários de manejo florestal incorporam uma parte considerável da sabedoria, conhecimento, habilidades práticas e do manejo necessário para a sustentabilidade dos recursos florestais a nível global. Estes sistemas, no entanto, se encontram ameaçados de várias maneiras, inclusive pelas rápidas mudanças do seu contexto político, socioeconômico e biofísico. Adaptar o manejo florestal no mesmo ritmo, a fim de poder lidar com estas mudanças, é um desafio de caráter urgente.

Este guia introduz critérios e indicadores (C\&I) de sustentabilidade em florestas manejadas de forma comunitária como uma ferramenta de aprendizado e comunicação que possa ajudar a enfrentar este desafio. 0 referido trabalho se baseia na pesquisa colaborativa do CIFOR com critérios e indicadores em países como o Brasil, a Indonesia, e os Camarões, propondo uma flexível abordagem passo-a-passo, destinado a desenvolver e implementar sistemas de monitoramento florestais, com exemplos de C\&l desenvolvidos por comunidades nestes países. Esta abordagem é direcionada à comunidades e seus parceiros no manejo florestal, tais como ONGs, governos, ou projetos de desenvolvimento a procura de estratégias para melhorar o bem-estar local e a sustentabilidade florestal através de um aprendizado mais efetivo, bem como ações conjuntas e decisões institucionais referentes ao manejo florestal local".

ISBN 979-8764-64-1
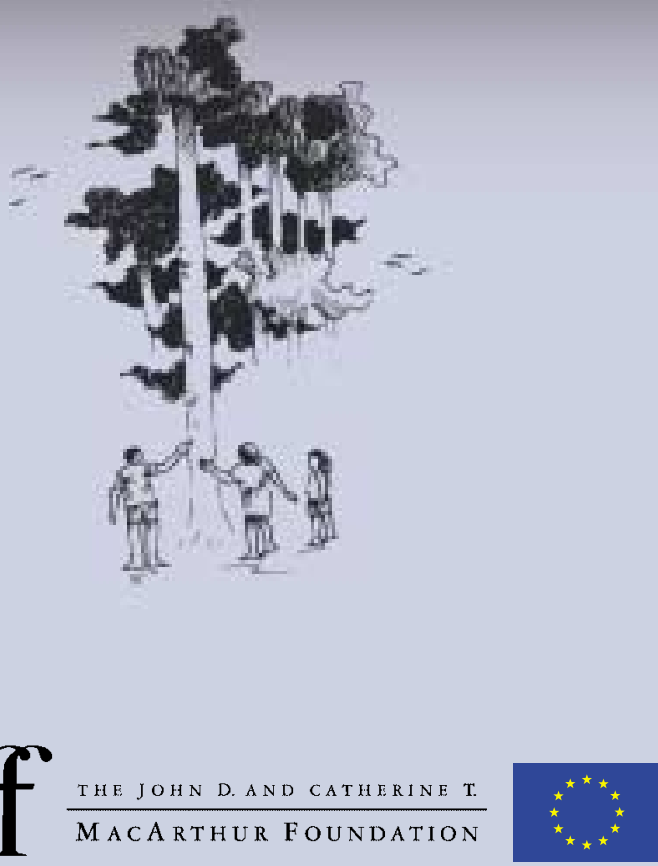